\title{
Assessment of groundwater potential zone using MCDA and AHP techniques: case study from a tropical river basin of India
}

\author{
Anitabha Ghosh ${ }^{1} \cdot$ Partha Pratim Adhikary $^{2} \cdot$ Biswajit Bera $^{3} \cdot$ Gouri Sankar Bhunia ${ }^{4} \cdot$ Pravat Kumar Shit $^{1}$
}

Received: 26 August 2021 / Accepted: 22 November 2021 / Published online: 11 February 2022

(c) The Author(s) 2022

\begin{abstract}
Shortage of potable water is a global problem, and this problem can be met by searching new areas where groundwater is available. GIS is an effective and necessary tool to identify groundwater potential zones in an area. In the present study, groundwater potential zones (GWPZs) were identified in the Kangsabati River basin of east India having an area of about $6488 \mathrm{~km}^{2}$ using multi-criteria decision analysis (MCDA) and analytical hierarchy process (AHP). The criteria like geology, geomorphology, elevation, slope, drainage, lineament, curvature, topographic wetness, land use/land cover, and soil were extracted from satellite data and the weights for each parameter and its sub-parameters were assigned through analytical hierarchy process based on their respective relevance as influencing factors for groundwater recharge. Very low, low, moderate, high, and very high groundwater potentiality represent $28.93 \%, 30.56 \%, 19.75 \%, 14.62 \%$, and $6.11 \%$ area, respectively. The low-lying flat plains of the southeastern section, as well as the centrally located dam, are ideal for groundwater recharge, while the upland plain of the northwestern part, with its hard rock terrain, is less so. This outcome has been verified using pre-monsoon and post-monsoon groundwater depth data, indicating that the strategy is most appropriate for this region. Thus, the groundwater potential zone maps remain very useful for conducting extensive ground-based hydrogeological studies that facilitate the identification of suitable bore well/dug well sites.
\end{abstract}

Keywords Analytic hierarchy process · Geospatial technique · GIS · Groundwater potential zone $\cdot$ Kangsabati River basin . Remote sensing $\cdot$ ROC curve

Anitabha Ghosh

anitabhaghosh@gmail.com

Partha Pratim Adhikary

Partha.Adhikary@icar.gov.in; ppadhikary@gmail.com

Biswajit Bera

biswajitbera007@gmail.com

Gouri Sankar Bhunia

rsgis6gouri@gmail.com

Pravat Kumar Shit

pravatgeo2007@gmail.com

1 PG Department of Geography, Raja N. L. Khan Women's College (Autonomous), Gope Palace, Midnapore, West Bengal 721102, India

2 ICAR Indian Institute Water Management, Bhubaneswar, Odisha 751023, India

3 Department of Geography, Sidho Kanho Birsha University, Purulia, India

4 Department of Geography, Seacom Skills University, Santiniketan, West Bengal, India

\section{Introduction}

Water is an important life-giving resource on the planet. It is the basic material that is required for life to exist. It has played a vital role in the formation of society since the dawn of human civilization. Water is widely dispersed on the planet, yet its quality and quantity fluctuate over time and location. Only $3 \%$ of the overall water resource is fresh, with the majority of freshwater being trapped as ice. Approximately $34 \%$ of the total water resource appears in the form of groundwater. Lakes and rivers contain less than $1 \%$ of all freshwater (Holden 2014). Freshwater allocation in the world is 2.50 percent, with groundwater accounting for only 1.69 percent (Te Chow 2008). Groundwater provides 34 percent of the world's freshwater sources to human society (Dar et al. 2010; Ghosh et al. 2016; Murmu et al. 2019). It is the surface water that seeps into the ground through the processes called infiltration and percolation. Groundwater is a primary hot spot for industries, communities, and agricultural consumption on the planet. The amount of groundwater 
on earth is assessed at in excess of 50 million cu. $\mathrm{km}$. Of this, $4 \mathrm{M} \mathrm{km}^{3}$ is considered as a sensible amount of crisp water that could be misused, which bars water that will not deplete from little pore spaces, saline water, and water lying somewhere down in restricted aquifers.

For domestic purposes, about 90 and $50 \%$ of rural and urban Indians, respectively, rely on groundwater (Central Ground Water Board 2014; Das et al. 2018). Groundwater is under stress as a result of expanding population, urbanization, agricultural, and industrial activities, and it is difficult to meet these needs with current groundwater resources (Saha, 2017). The demand for water is quickly increasing as a result of rapid urbanization and extraordinary population expansion (Choudhary et al. 1996). Groundwater is the greatest exploitable supply of freshwater, accounting for around 34\% of the world's freshwater (Sharma and Kujur, 2012; Neelakantan and Yuvaraj, 2012). Due to rising industrialization and population expansion, demand for this natural resource is escalating, resulting in scarcity in some areas, and it plays a significant part in global climate change and meeting basic needs. Various industries, particularly agriculture, manufacturing, and energy, have seen remarkable progress in the previous few decades. This has led to growing demand for irrigation, domestic, and industrial needs (Singh et al. 2011).

Groundwater is a life-sustaining resource. The increasing demand for groundwater in India was observed during the 1970s as a major impact of the Green Revolution. Since the beginning of the Green Revolution, groundwater variations have been observed in various parts of India. Numerous states in India are experiencing a severe groundwater shortage, and various studies have been done to determine groundwater prospective zones. Groundwater prospective zones have been recovered with the aid of remote sensing data and a GIS technique in the states of Tamil Nadu, Karnataka, Uttar Pradesh, and a few other parts of India (Ramu et al. 2014; Ali et al. 2015; Pande et al. 2017; Das et al. 2018).

Groundwater is a valuable natural resource that plays a vital part in the economy. It is one of the primary sources of water for agricultural irrigation and human consumption. Around $43 \%$ of groundwater resources are mainly used for agricultural activities. It plays a very important role during the drier months where there is a little direct recharge from rainfall mainly in the monsoonal countries of southeast Asia. It plays an important role in the wildlife and plants to survive in those high temperatures. Groundwater also plays an important role in increasing the water levels in rivers. Because of its storage underneath the surface, it is less contaminated with the pollution and hence it does not require large investments in treatment. Groundwater recharge, also known as deep percolation, is a hydrologic process in which water travels downward from the surface to the ground, with two types of recharge: natural and artificial. Various methods are available to find groundwater recharge potential zones, which are a) geological technique, b) hydrogeological technique, c) geophysical technique, and d) remote sensing technique (Adhikary et al. 2015). Among them, remote sensing technique is the best way as other techniques require physical appearance at the study area and require so much knowledge to adapt them.

Many elements, including geology, geomorphology, drainage, slope, depth of weathering, existence of fractures, surface water bodies, canals, and irrigated crops, all influence groundwater potential in a specific location (Jain,1998; Nag and Ghosh, 2012). When the groundwater quality deteriorates, it might be due to the cumulative effect of two or many factors. To understand the cause of deterioration of overall groundwater quality, all these factors need to be analyzed. In certain places of India, limitations of this valuable resource have resulted from a lack of scientific planning and excessive consumption (Tiwari et al. 2017). The downward trend in water levels is quite worrying, as it will result in a long-term groundwater issue (Das and Mukhopadhyay, 2018). As a result, groundwater management is required for the restoration of this renewable resource. One of the essential components of this strategy implementation is to increase groundwater recharge (Baalousha et al. 2018). To get the effective recharge potential zones, multi-criteria decision analysis (MCDA) is a must where we can have a glimpse of influence of all the possible criteria on overall quality and recharge possibility.

Various models and quantitative methodologies (Prasad et al. 2008) like multi-influencing factor (Magesh et al. 2012), weighted overlay model (Sajikumar and Pulikkottil, 2013), logistic regression model (Pourtaghi and Pourghasemi, 2014), frequency ratio model (Razandi et al. 2015), and certainty factor model (Razandi et al. 2015) are being used globally to assess the groundwater potential zones. Out of these many models, the widely utilized tool for groundwater management is multi-criteria decision analysis (MCDA) (Madrucci et al. 2008; Jha et al. 2010; Rahmati et al. 2015). Saaty proposed the analytic hierarchy process (AHP) as a commonly used model of MCDA for solving socioeconomic decision-making concerns (Jhariya et al. 2016). Furthermore, the AHP model emphasizes not just individual elements, but groups of elements that are frequently required (Saaty 1999). The AHP model was used in this work to give relative importance to each groundwater prospecting parameter, which clarifies groundwater potential zone (Hajkowicz and Higgins 2008; Murthy and Mamo 2009; Chowdhury et al. 2009; Kaliraj et al. 2014). The major goal of this research is to identify groundwater prospective zones in the Kangsabati River basin using the AHP method and GIS approach, as well as the unification of eleven groundwater prospective criteria. Such quantitative research methods and 
the use of GIS techniques to analyze groundwater potential zones will aid planners and decision-makers in determining the best place for borehole drilling and long-term groundwater management.

\section{Materials and methods}

\section{Location of the study area}

The Kangsabati is a non-perennial river that flows through Purulia, Bankura, Paschim, and Purba Midnapore districts of West Bengal (India). It originates on the Chhotanagpur plateau edge in Jharkhand. The Kangsabati basin is a tropical plateau fringe basin that stretches from Jharkhand's Chhotanagpur plateau to the Rupnarayan and Kheliaghai basins in the lower Gangetic Plain. This basin has a latitudinal extension of $21^{\circ} 30^{\prime} \mathrm{N}-23^{\circ} 30^{\prime} \mathrm{N}$ and a longitudinal extension of $85^{\circ} 45^{\prime} \mathrm{E}-88^{\circ} 15^{\prime} \mathrm{E}$, covering an area of $9658 \mathrm{~km} 2$ (Bhattacharya 2018). In this study, a total area of $6487.90 \mathrm{~km} 2$ was used to assess the groundwater prospective zone (Fig. 1).

The top half of the plateau-plain sub-humid river basin is governed by rolling dissected plateau region, which is dominated by Pre-Cambrian granite, gneiss geological formation. The intermediate parts of the basin are dominated by primary and secondary laterite development, whereas the lower plain portions are dominated by alluvial deposition. Streamflow characteristics are dominated by lower water regimes and seasonal rainfall. It originates on the eastern Chhotanagpur plateau's "Ajodhya Hill" and runs eastward through the plateau fringe region of West Bengal (Nag and Lahiri 2012). The fragmented Chhotanagpur plateau covers roughly $200 \mathrm{~km}$ in the top and middle parts of the basin, out of a total length of $465 \mathrm{~km}$. According to research, the basin is in the latter stages of geomorphic evolution (Dutta and Roy 2012; Pan 2013).

\section{Data procurement and use}

To carry out the study and generate a groundwater potential map with appropriate accuracy, we procured Survey of India (SOI) Toposheet, accessible credible data and maps, rainfall data, remote sensing data, GIS software (ArcGIS, ERDAS IMAGINE, ENVI, PCI Geomatica, etc.), statistical software (SPSS), and GPS.

\section{Preparation of thematic layers}

The Kangsabati Basin's GWPZ was defined using a variety of hydrogeological factors, including geology,

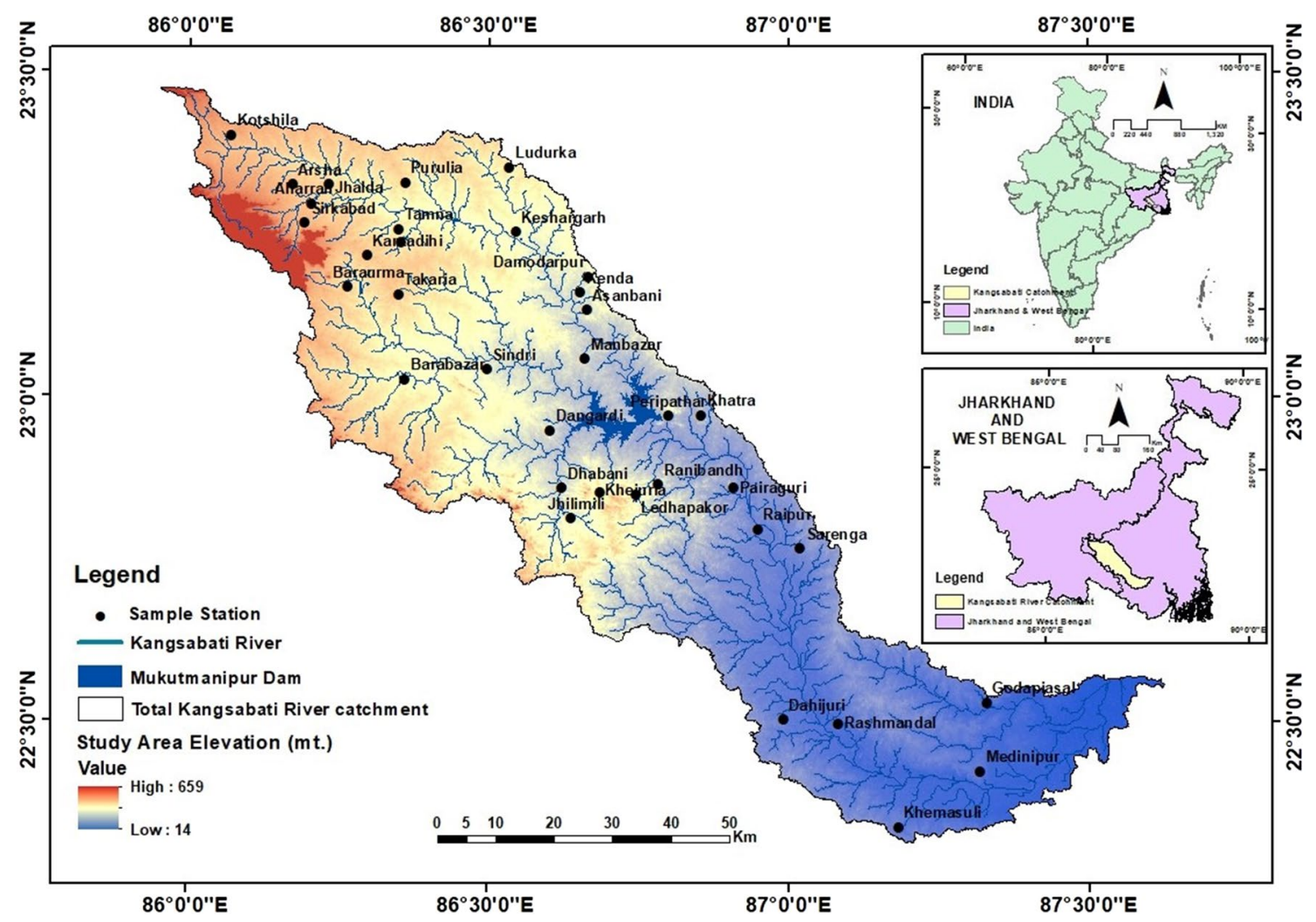

Fig. 1 Location map of the study area showing the sampling points and drainage network of Kangsabati River basin 
geomorphology, elevation, slope, drainage density, lineament, curvature, topographic wetness index, soil, rainfall, and land use/land cover (Table 1). In the first step, all of the data were scanned and converted to raster format, as well as georeferenced to the universal transverse Mercator projection and datum WGS1984. On a 1:50,000 scale, a base map of the Kangsabati River basin was created using SOI topographical sheets $(73 \mathrm{I} / 10,11,12,13,73 \mathrm{~J} / 9,15,73 \mathrm{~N} / 2$, $3,4,5,7,8)$. In ArcGIS, the SOI topographical maps were georeferenced using the WGS 84 datum and the UTM zone $45^{\circ} \mathrm{N}$ projection. Geology, geomorphology, land use/land cover, elevation, drainage density, slope, curvature, lineament, topographic wetness index, rainfall, and soil type were all addressed in this research as contributing factors for groundwater recharge. All contributing factors are classified after Jenks Natural Breaks classification system (Jenks 1967). The methodological flowchart in this study is presented in Fig. 2. Using the spatial analysis tool in ArcGIS, a slope and altitude map of the Kangsabati basin was constructed from ASTER GDEM (30 m). On a GIS platform, a land use and land cover (LULC) map of the basin was created using the maximum likelihood supervised classification approach. Landsat 8 satellite imageries were utilized to create the LULC map. Drainage networks were digitized from georeferenced topographical maps (73I/10, 11, 12, 13, $73 \mathrm{~J} / 9,15,73 \mathrm{~N} / 2,3,4,5,7,8)$ and current drainage development from Google Earth images to create a drainage density map for the basin. ASTER DEM was chosen to create a stream network in the Kangsabati basin. Flow direction and flow accumulation raster computation sub-tools were utilized in ArcGIS spatial analysis tools to build stream networks. The raster streams were vectorized using conversion software (Raster to polyline). Finally, using the line density tool in the ArcGIS environment, a drainage density map of the Kangsabati basin was created. ENVI, PCI Geomatica, and ArcGIS tools were used to prepare geology and lineaments from a Geological Quadrangle Map with a scale of $1: 2,50,000$. BHUVAN thematic services, supplied by the National Remote Sensing Centre (NRSC), Hyderabad, were used to extract geomorphic traits and attributes of the basin. The soil map was created using NBSSLUP's West Bengal soil map at a scale of 1:2,50,000, and the average yearly rainfall was calculated using University of East Anglia's Climatic Research Unit (CRU)-UEA's average rainfall data (2010-2019). Georeferenced SOI Toposheet of 1: 50,000 was resampled into 1:2,50,000 scale, and all the data layers were calibrated to bring in the same scale of 1:2,50,000.

\section{Weightage analysis and normalization of AHP}

The weightage of criterion and sub-criteria of the thematic layers is examined using the analytic hierarchy process (AHP). The AHP (Saaty 1980; Saaty and Vargas 1991) is a well-known means of multi-criteria technique which has been incorporated into the GIS-based suitability procedures (Jankowski and Richard, 1994; Marinoni, 2004). Each thematic map was resampled to a $30 \mathrm{~m} \times 30 \mathrm{~m}$ pixel raster picture. AHP aids decision-making by combining various factors into a pair-wise comparison matrix. It uses a preference matrix to determine the requisite weighting factors, comparing all determined necessary criteria against each other with consistent preference factors, and then accumulates the weights of criterion map layers in a manner similar to weighted linear combination (WLC) approaches (Chen et al. 2010). The AHP approach can be used to arrange both quantitative (objective) and qualitative (subjective)

Table 1 Details of data sources used for thematic layers preparation

\begin{tabular}{|c|c|c|c|}
\hline Thematic layers & Data type & Scale/Resolution & Data sources \\
\hline Base Map (Topographical Map) & Polygon & $1: 50,000$ & Survey of India (SOI) (http://www.surveyofindia.gov.in) \\
\hline Elevation & \multirow{6}{*}{$\begin{array}{l}\text { Raster } \\
\text { (ASTER DEM) }\end{array}$} & \multirow[t]{6}{*}{$30 \mathrm{~m}$ (spatial resolution) } & USGS Earth Explorer (https://earthexplorer.usgs.gov/) \\
\hline Slope & & & \multirow[t]{5}{*}{ Data of Years 2019 (Nov. -Dec.) } \\
\hline Lineament & & & \\
\hline Curvature & & & \\
\hline Drainage Density & & & \\
\hline TWI & & & \\
\hline Geology & Polygon & $1: 250,000$ & $\begin{array}{l}\text { Geological Survey of India (GSI) (http://www.portal.gsi. } \\
\text { gov.in) }\end{array}$ \\
\hline Geomorphology & Polygon & $1: 250,000$ & $\begin{array}{l}\text { Geological Survey of India (GSI) (http://www.portal.gsi. } \\
\text { gov.in) }\end{array}$ \\
\hline Soil & Polygon & $1: 50,000$ & NBSS \& LUP (http://www.nbsslup.in) \\
\hline Rainfall & Raster & 1 sq. km (spatial resolution) & UEA-CRU Global Climate Data of Years 2010-2019 \\
\hline Land-use/Land-cover & Landsat $8 \mathrm{OLI} / \mathrm{TM}$ & $30 \mathrm{~m}$ (spatial resolution) & USGS (https://earthexplorer.usgs.gov/) \\
\hline Depth to water level & Point & & $\begin{array}{l}\text { Central Ground Water Board, CGWB (2019-2020) WB } \\
\text { \& AN }\end{array}$ \\
\hline
\end{tabular}




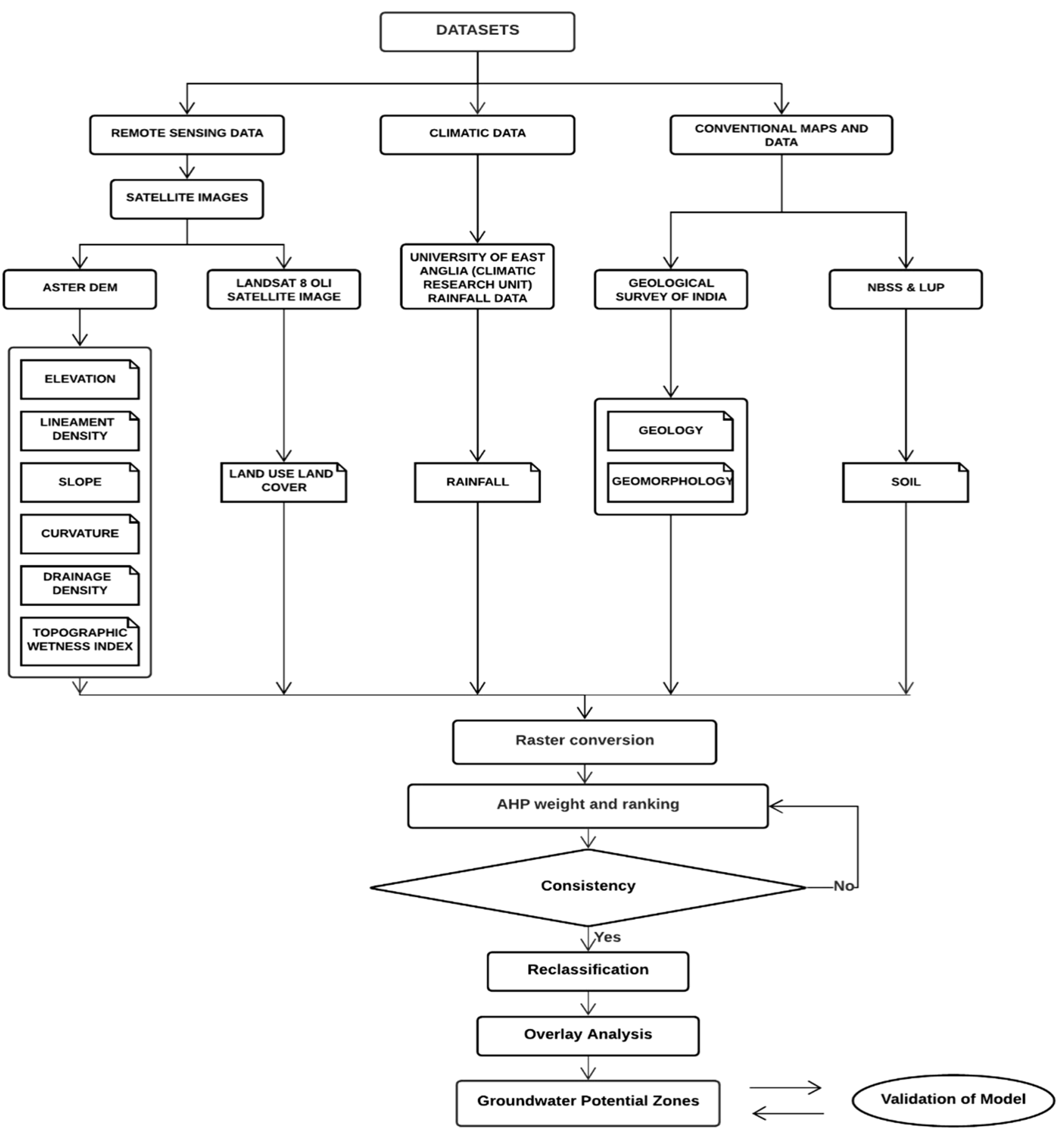

Fig. 2 Methodological flow-chart used in this study for groundwater potential zone mapping

information concerning decision-making analysis. Based on their relative relevance, each criterion was given a rank from 1 to 9 (Table 2). All of these elements were given a relative measure based on various criteria and preferences (1, equally important; 3 , slightly important; 5 , quite important; 7, extremely important; 9 , absolutely important; 2,4 , 6 , and 8 are intermediate values). The criteria were analyzed accordingly using the AHP matrix (Table 3, Table 4). The value " 1 " is organized diagonally in this matrix, which has an equal number of columns and rows. The relative relevance of two criteria is determined in each row. The first row of the matrix reflects the importance of a criterion in relation to 11 other criteria in the matrix's column. The rows show the inverse value of each criterion and its relationship to other criteria. (Geology is more important than lineament density; so, geology has a value of 1 and lineament has a value of 2 ; 
Table 2 Description of scales for pair comparison with AHP ( Source: Satty, 1990)
Table 3 Pair-wise comparison matrix for all factors

\begin{tabular}{lll}
\hline Scales & Degree of preferences & Descriptions \\
\hline 1 & Equally important & The contribution of the two factors is equally important \\
3 & Slightly important & Experiences and judgment Slightly tend to certain factor \\
5 & Quite important & Experiences and judgment Strongly tend to certain factor \\
7 & Extremely important & Experiences and judgment extremely strongly tend to certain factor \\
9 & Absolutely important & There is sufficient evidence for absolutely tending to certain factor \\
$2,4,6,8$ & Intermediate values & In between two judgment \\
\hline
\end{tabular}

\begin{tabular}{llllllllllll}
\hline Factors & GG & LD & GM & SL & E & LULC & DD & RF & S & C & TWI \\
\hline Geology (GG) & 1 & 2 & 3 & 5 & 5 & 6 & 6 & 7 & 8 & 9 & 9 \\
Lineament Density (LD) & 0.5 & 1 & 2 & 3 & 3 & 4 & 5 & 6 & 7 & 8 & 9 \\
Geomorphology (GM) & 0.33 & 0.5 & 1 & 3 & 3 & 4 & 5 & 6 & 7 & 8 & 8 \\
Slope (SL) & 0.2 & 0.33 & 0.33 & 1 & 2 & 3 & 5 & 6 & 7 & 8 & 9 \\
Elevation (E) & 0.2 & 0.33 & 0.33 & 0.5 & 1 & 2 & 4 & 5 & 6 & 7 & 8 \\
Land-use/Land-cover (LULC) & 0.17 & 0.25 & 0.25 & 0.33 & 0.5 & 1 & 2 & 3 & 4 & 5 & 6 \\
Drainage Density (DD) & 0.17 & 0.2 & 0.2 & 0.2 & 0.25 & 0.5 & 1 & 2 & 4 & 6 & 8 \\
Rainfall (RF) & 0.14 & 0.17 & 0.17 & 0.17 & 0.2 & 0.33 & 0.5 & 1 & 2 & 4 & 5 \\
Soil (S) & 0.13 & 0.14 & 0.14 & 0.14 & 0.17 & 0.25 & 0.25 & 0.5 & 1 & 2 & 4 \\
Curvature (C) & 0.11 & 0.13 & 0.13 & 0.13 & 0.14 & 0.2 & 0.17 & 0.25 & 0.5 & 1 & 3 \\
Topographic Wetness Index (TWI) & 0.11 & 0.11 & 0.13 & 0.11 & 0.13 & 0.17 & 0.13 & 0.2 & 0.25 & 0.33 & 1 \\
\hline
\end{tabular}

Table 4 Pair-wise comparison matrix, weights and consistency ratio for the data layers used

\begin{tabular}{|c|c|c|c|c|c|c|c|c|c|c|c|c|}
\hline Thematic Layer & GG & $\mathrm{LD}$ & GM & SL & $\mathrm{E}$ & LULC & DD & $\mathrm{RF}$ & $\mathrm{S}$ & $\mathrm{C}$ & TWI & Weights \\
\hline Geology (GG) & 0.3271 & 0.3874 & 0.3908 & 0.3682 & 0.325 & 0.2797 & 0.2066 & 0.1894 & 0.1711 & 0.1543 & 0.1286 & 0.266214 \\
\hline Lineament Density (LD) & 0.1636 & 0.1937 & 0.2605 & 0.2209 & 0.195 & 0.1865 & 0.1722 & 0.1624 & 0.1497 & 0.1371 & 0.1286 & 0.179112 \\
\hline Geomorphology (GM) & 0.109 & 0.0969 & 0.1303 & 0.2209 & 0.195 & 0.1865 & 0.1722 & 0.1624 & 0.1497 & 0.1371 & 0.1143 & 0.152209 \\
\hline Slope (SL) & 0.0654 & 0.0646 & 0.0434 & 0.0736 & 0.13 & 0.1399 & 0.1722 & 0.1624 & 0.1497 & 0.1371 & 0.1286 & 0.115175 \\
\hline Elevation $(\mathrm{E})$ & 0.0654 & 0.0646 & 0.0434 & 0.0368 & 0.065 & 0.0932 & 0.1377 & 0.1353 & 0.1283 & 0.12 & 0.1143 & 0.091288 \\
\hline LanduseLandcover (LULC) & 0.0545 & 0.0484 & 0.0326 & 0.0245 & 0.0325 & 0.0466 & 0.0689 & 0.0812 & 0.0856 & 0.0857 & 0.0857 & 0.058749 \\
\hline Drainage Density (DD) & 0.0545 & 0.0387 & 0.0261 & 0.0147 & 0.0163 & 0.0233 & 0.0344 & 0.0541 & 0.0856 & 0.1029 & 0.1143 & 0.051352 \\
\hline Rainfall (RF) & 0.0467 & 0.0323 & 0.0217 & 0.0123 & 0.013 & 0.0155 & 0.0172 & 0.0271 & 0.0428 & 0.0686 & 0.0714 & 0.03351 \\
\hline Soil (S) & 0.0409 & 0.0277 & 0.0186 & 0.0105 & 0.0108 & 0.0117 & 0.0086 & 0.0135 & 0.0214 & 0.0343 & 0.0571 & 0.023195 \\
\hline Curvature (C) & 0.0363 & 0.0242 & 0.0163 & 0.0092 & 0.0093 & 0.0093 & 0.0057 & 0.0068 & 0.0107 & 0.0171 & 0.0429 & 0.017078 \\
\hline $\begin{array}{l}\text { Topographic Wetness Index } \\
\text { (TWI) }\end{array}$ & 0.0363 & 0.0215 & 0.0163 & 0.0082 & 0.0081 & 0.0078 & 0.0043 & 0.0054 & 0.0053 & 0.0057 & 0.0143 & 0.012118 \\
\hline Principal Eigenvalues & 12.191 & & & & & & & & & & & \\
\hline Consistency Ratio (CR) & 0.0788 & & & & & & & & & & & \\
\hline
\end{tabular}

thus, lineament density has a value of $1 / 2$ in the following row.) To test whether or not the pair-wise comparisons were consistent, the consistency ratio (CR) was determined. The advantage of the AHP technique is that it accommodates for inconsistencies while still delivering a CR as a measure of consistency or inconsistency (Chen et al. 2010; Feizizadeh and Blaschke, 2013; Bera et al. 2019). When the consistency ratio is less than 0.10 , a reasonable level of consistency can be assumed when computing the weights (Table 5) of the various criteria.

$$
\text { Consistensy Ratio }(C R)=\frac{\text { Consistensy Index }(C I)}{\text { Random Consistensy Index }(C I)}
$$

Consistensy Index $(C I)=\frac{\left(\lambda_{\max }-n\right)}{n-1}$ 


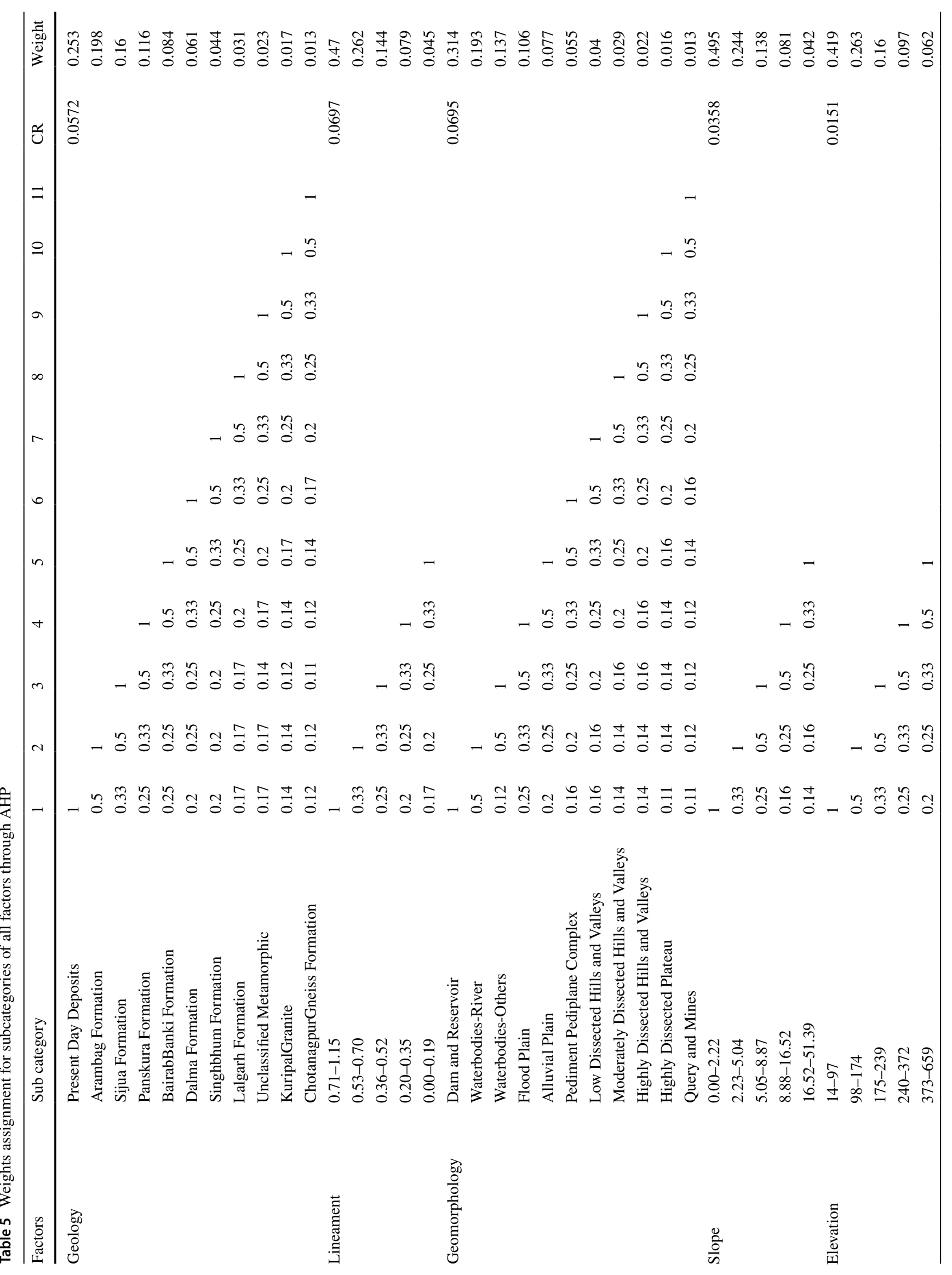




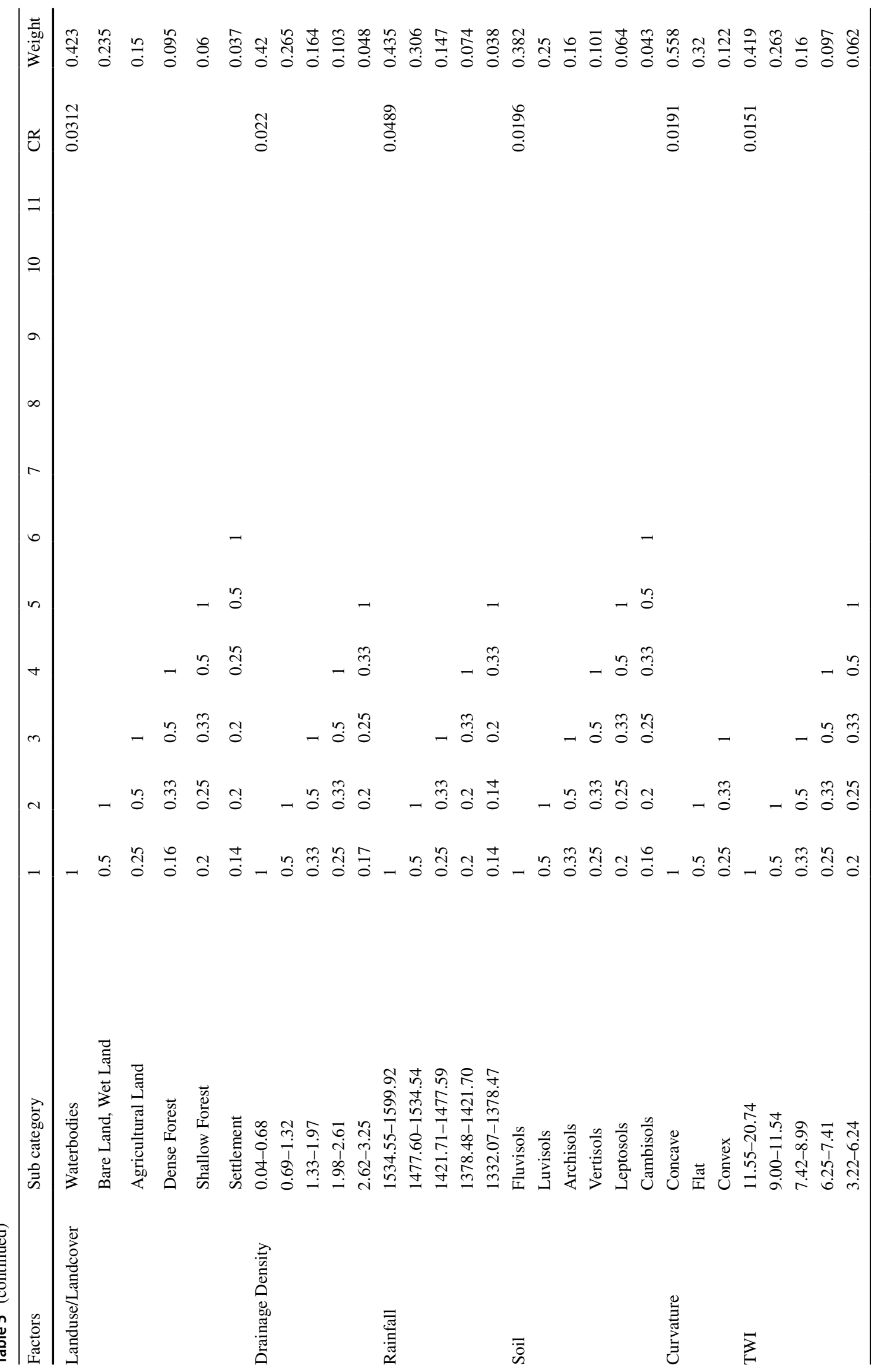


Table 6 Random index value used for the study ( Source: Satty, 1990)

\begin{tabular}{llllllllllllllll}
\hline $\mathrm{n}$ & 1 & 2 & 3 & 4 & 5 & 6 & 7 & 8 & 9 & 10 & 11 & 12 & 13 & 14 & 15 \\
\hline $\mathrm{RI}$ & 0 & 0 & 0.58 & 0.9 & 1.12 & 1.24 & 1.32 & 1.41 & 1.45 & 1.49 & 1.51 & 1.53 & 1.56 & 1.57 & 1.59
\end{tabular}

$\mathrm{n}$ stands for the number of considering factors and RI is the random consistency index where $\lambda_{\max }$ is the principal eigenvalue; $n$ stands for the number of considering factors; $\lambda_{\max }=\sum$ of the products between each element of the priority vector and column totals. Random consistency index (RI) was evaluated from a sample of "randomly generated reciprocal matrices" (Saaty 1990) (Table 6). The CR value of 0.078 suggested acceptable consistency for weight analysis and was appropriate for identifying the GPZ in this investigation.

The class that had the most suited, quality, and potential in each factor map was given the most weight. The class with the least potential, on the other hand, received the lowest weight. Groundwater recharge was used to offer a weight to each thematic data layer. The weight of the specified thematic map was computed using Satty's analytical hierarchy technique and a pair-wise comparison matrix (Saaty 1990). On a scale of 0-9, classes of each factor were graded according to their relative importance on groundwater recharge. Furthermore, for groundwater potential zonation, a linear weightage sum combination approach was used by integrating the weight and ranking of the individual components and each class, respectively, in an RS-GIS environment. determined by it. Kuripal granite, Chhotanagpur gneiss complex, unclassified metamorphic, Lalgarh, Singhbhum, Dalma, Bhairabbanki, Panskura, Sijua, Arambagh, and present-day alluvial deposit are among the geological formations found in the basin (Fig. 3). The Chhotanagpur gneiss complex, Singhbhum, and unclassified metamorphic formations comprise the upper basin area, accounting for 30.78 percent, 30.48 percent, and 3.46 percent of the entire study area, correspondingly. The lower part is mainly dominated by Bhairabbanki, Panskura, Sijua, Arambagh, Lalgarh, and present-day alluvial deposit formation covering $0.37 \%$, $2.87 \%, 12.46 \%, 4.37 \%, 11.34 \%$, and $1.03 \%$ of the study area, respectively. From the Kangsabati River basin's basement rock system, the oldest rock system consists of granite, granite gneiss, and mica schist. Unclassified crystalline minerals, predominantly gneiss, granite gneiss, and mica schist, cover the upper course of the Kangsabati basin. Alluvium and recent alluvial deposits have overlaid the laterite and meta-volcanic rock found in the middle and lower basins. Structural instabilities in the Kangsabati basin have taken the shape of lineament and joints. The main deformations

$$
\begin{aligned}
G W P I= & \left(G G_{W}\right)\left(G G_{W i}\right)+\left(L D_{W}\right)\left(L D_{W i}\right)+\left(G M_{W}\right)\left(G M_{W i}\right)+\left(S L_{W}\right)\left(S L_{W i}\right) \\
& +\left(E_{W}\right)\left(E_{W i}\right)+\left(L U L C_{W}\right)\left(L U L C_{W i}\right)+\left(D D_{W}\right)\left(D D_{W}\right)+\left(R F_{W}\right)\left(R F_{W i}\right) \\
& +\left(S_{W}\right)\left(S_{W i}\right)+\left(C_{W}\right)\left(C_{W i}\right)+\left(T W I_{W}\right)\left(T W I_{W i}\right)
\end{aligned}
$$

where $G W P I=$ groundwater potential index, $G G=$ geology, $L D=$ lineament density, $G M=$ geomorphology, $S L=$ slope, $E=$ elevation, $L U L C=$ land use/land cover, $D D=$ drainage density, $R F=$ rainfall, $S=$ soil type, $C=$ curvature, $T W I=$ topographic wetness index, and the subscripts " $w$ " and "wi" refer to the normalized weight of a factor and the normalized weight of the individual class of a factor. Here, GWPI is a unit less amount to find out probable groundwater indexing in the area.

\section{Results and discussion}

\section{Thematic layers for GWPZ}

\section{Geology}

Because the geological setting of a place has such a big impact on surface runoff, infiltration, and seepage, the presence and dissemination of groundwater are primarily extend from northeast to southwest. Weathered aquifers in the lower course of the alluvial plain and fractured aquifers in the upper basin granite gneiss geological formation were also found in the Kangsabati basin (Mahala 2020).

\section{Lineament density}

Lineaments are linear or curvilinear characteristics on the earth's surface that are an apparent representation of an underpinning lithological structure including faults, fractures, and cleavages as observed by satellite imagery. The grid-based approach was used to calculate lineament density. It was defined as the total lineament length in the grid divided by the area of the grid (Edet et al. 1998).

$L d=\sum_{i=1}^{i=n} \frac{L i}{A}\left(k m^{-1}\right)$

where $\sum L i$ is the total lineament length in the grid $(\mathrm{km})$ and $A$ is the grid area $\left(\mathrm{km}^{2}\right)$. 


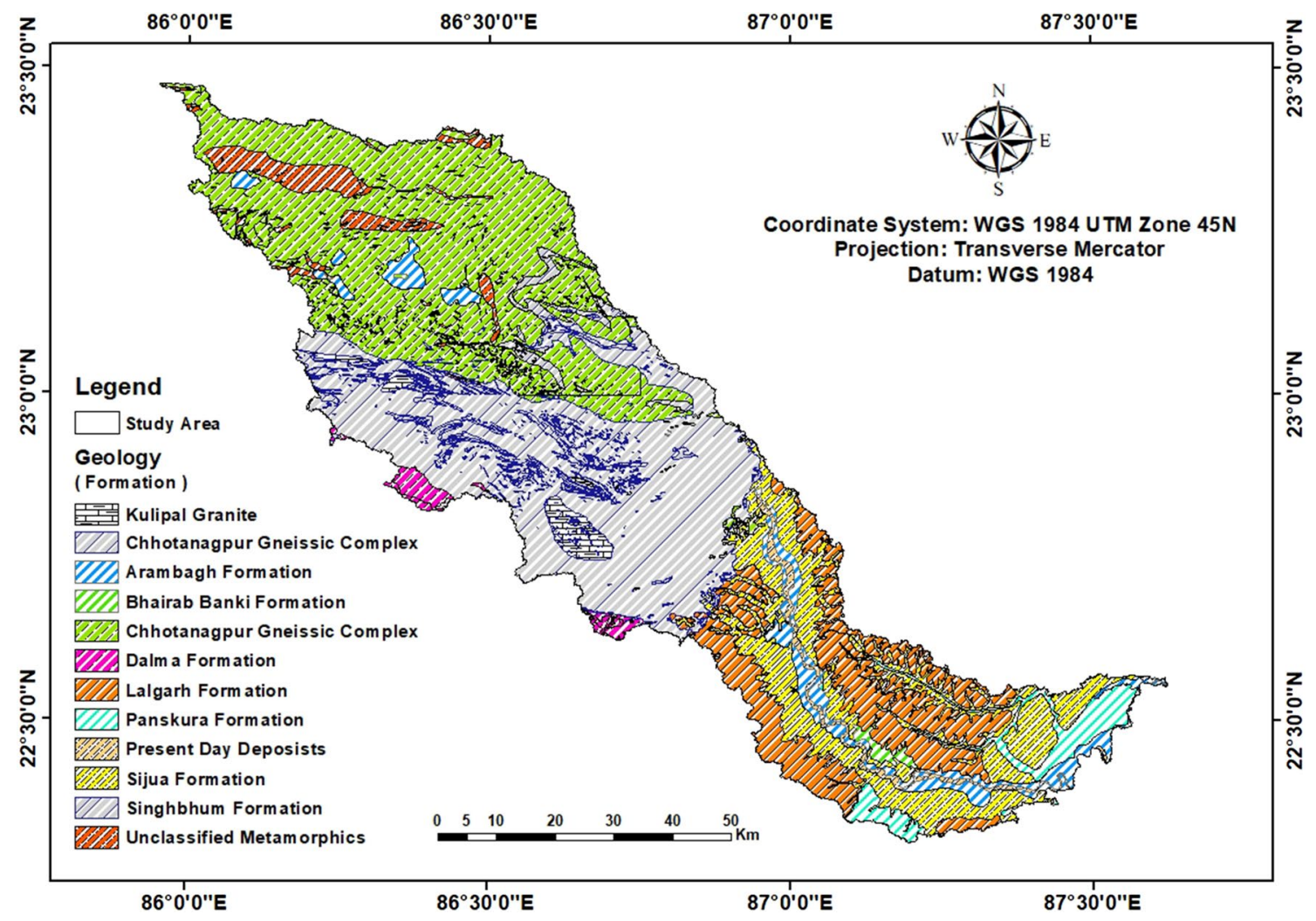

Fig. 3 Spatial map of geology showing different formations of Kangsabati River basin

Hard rock underpins the majority of the Kangsabati River basin, whereas lineaments generate secondary porosity and permeability, both of which are important for groundwater recharge. The primary fractures in the studied area run from north to south. The lineament density of the study area has been classified into five major classes, i.e., very low $\left(0.0-0.19 \mathrm{~km} / \mathrm{km}^{2}\right)$, low $\left(0.20-0.35 \mathrm{~km} / \mathrm{km}^{2}\right)$, moderately low $\left(0.36-0.52 \mathrm{~km} / \mathrm{km}^{2}\right)$, high $\left(0.53-0.70 \mathrm{~km} / \mathrm{km}^{2}\right)$, and very high $\left(0.71 .1 .15 \mathrm{~km} / \mathrm{km}^{2}\right.$ ) (Fig. 4). Groundwater development has a lot of potential in areas where lineament density is high to very high.

\section{Geomorphology}

The geomorphology of a given area is thought to be an important factor in determining the groundwater potential zone. It also aids in the comprehension of groundwater presence, prospect, and mobility. On a hard rock terrain, tectonic activity and denudational processes are the primary determinants of geomorphological evolution. The Kangsabati River basin comprises the following geomorphic features: pediment-pediplain complex, low dissected hills and valleys, moderately dissected hills and valleys, highly dissected hills and valleys, highly dissected plateau, alluvial plain, flood plain, anthropogenic terrain (dam and reservoir), and water bodies (Fig. 5). The massive pediment-pediplain multifaceted is found in the northwest, central, and southeastern part of the basin and covers an extensive part of the study area of which $75.82 \%$ consists of gneiss and lateritic formation. Lower part of the basin dominated by alluvial plain, flood plain, and water bodies covers $6.63 \%, 4.36 \%$, and $2.01 \%$ of the study area, respectively. Flood plain deposits and alluvial plains both contain abundant groundwater because of the high recharge rate and peak flow of river water during the monsoon season. The anthropogenic terrain (dam and reservoir) found in the central part and low dissected hills and valleys, moderately dissected hills and valleys, highly dissected hills and valleys, and highly dissected plateau is found in scattered position in central, northwest, and east central part of the study area.

\section{Slope}

The steepness of the ground surface is expressed by slope, which is a major terrain attribute. The grade of the slope is an essential terrain feature in determining the groundwater vulnerability. It has a direct impact on the penetration of surface water. A lower value of the slope angle resembles the flatter terrain, whereas the higher slope values indicate the steeper terrain. Because water flows fast downward on 


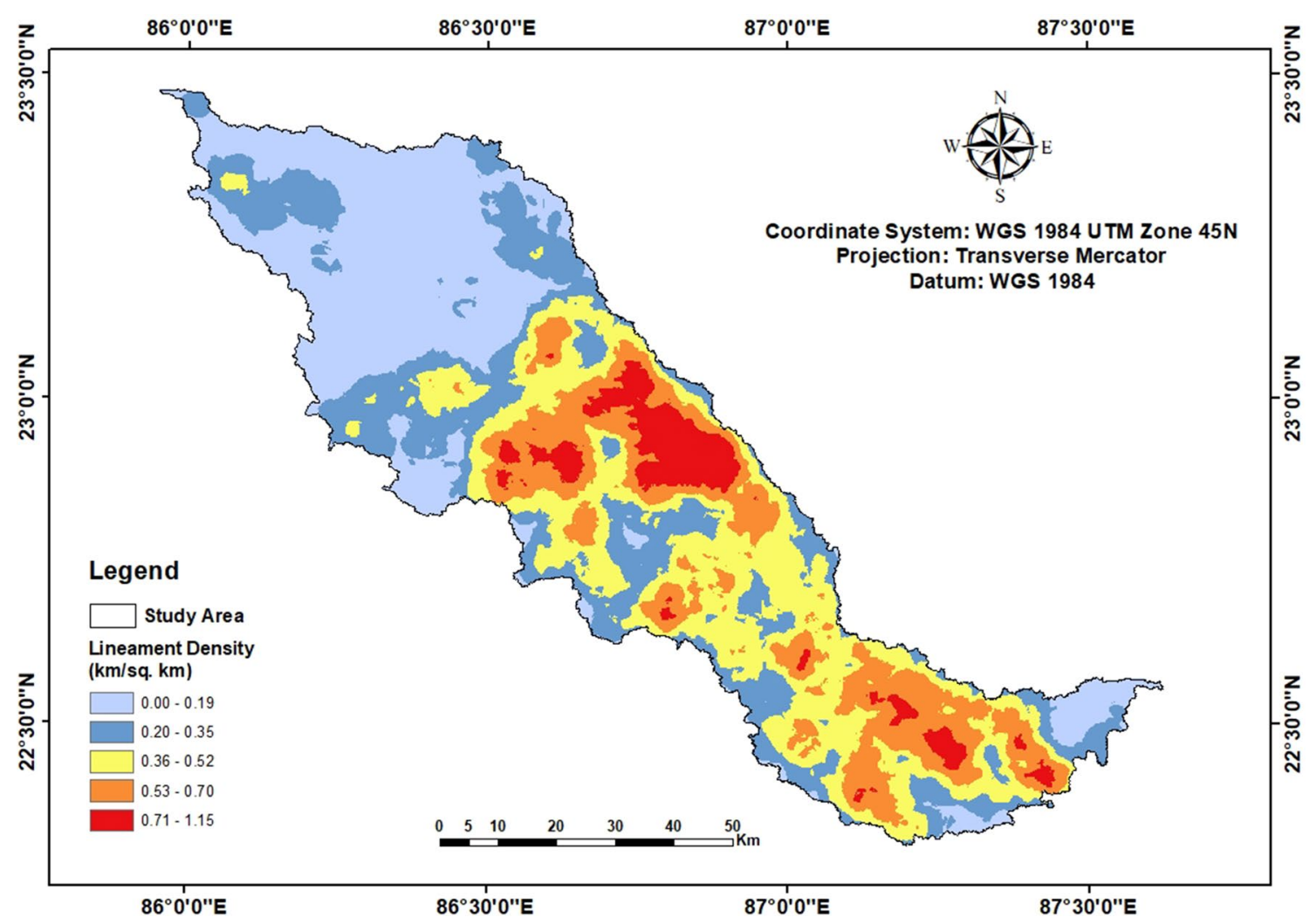

Fig. 4 Spatial distribution of lineament density of Kangsabati River basin

steep slopes, precipitation does not have enough time to assimilate; steep slopes are connected with limited recharge potential. Groundwater recharging can take longer in locations with gentle slopes. As a result, groundwater recharge is more likely in the gentle slope-dominated region than on steep slopes. A DEM was used to create the slope map for this research. The extended slope data were reclassified into five classes, namely flat $\left(0.00^{\circ}-2.22^{\circ}\right)$, gentle $\left(2.23^{\circ}-5.04^{\circ}\right)$, medium $\left(5.05^{\circ}-8.87^{\circ}\right)$, steep $\left(8.88^{\circ}-16.52^{\circ}\right)$, and very steep slopes $\left(>16.53^{\circ}\right)$ (Fig. 6). According to this classification system, the majority of the research area (39.20 percent) has a level terrain, whereas 0.82 percent to 5.09 percent of the area has a steep to very steep slope.

\section{Elevation}

Elevation is important in controlling the stream gradient, which determines the groundwater potentiality in a drainage basin from the highest to the lowest altitude per unit area (Patra et al. 2018; Das and Pal, 2020). Elevation range in the present study area has been classified into five classes, i.e., above 373-659 m (2.14\%), 240-372 m (21.19\%), 175-239 m (25.16\%), 98-174 m (19.63\%), and 14-97 m (31.86\%) (Fig. 7). The basin's elevation varies between 97 and $659 \mathrm{~m}$. Low groundwater concentrations range from 659 to $239 \mathrm{~m}$ above mean sea level $(\mathrm{msl})$ in the upper basin, owing to high altitude and limited infiltration capacity; however, maximum concentrations range from 97 to $14 \mathrm{~m}$ (msl) in the lower basin, owing to massive water logging and a low gradient ratio (CGWB 2014). Therefore, various weightage values have been assigned for different elevation.

\section{Land use/Land cover}

The magnitude of groundwater demand and consumption is determined by land use and land cover (Jhariya et al. 2016). It also offers information on groundwater recharge (Singh et al. 2011). The study area's land use and land cover map were created using Landsat- 8 satellite photographs obtained from USGS Earth Explorer and classified using ArcGIS 10 software's supervised classification algorithm. Land use and land covers have a great impact on hydrogeological and geo-hydroclimatic process in the water cycle, viz. runoff, infiltration process, and evapotranspiration. Groundwater recharge is influenced by these mechanisms. Water bodies, bare land/wetland, agricultural land, dense forest, shallow forest, and settlement are the six kinds of land use/land cover in the Kangsabati River basin (Fig. 8). The maximum area is dominated by dense forest and agricultural land which is above $50 \%$ of the study area. Bare land/wetland, settlement, 


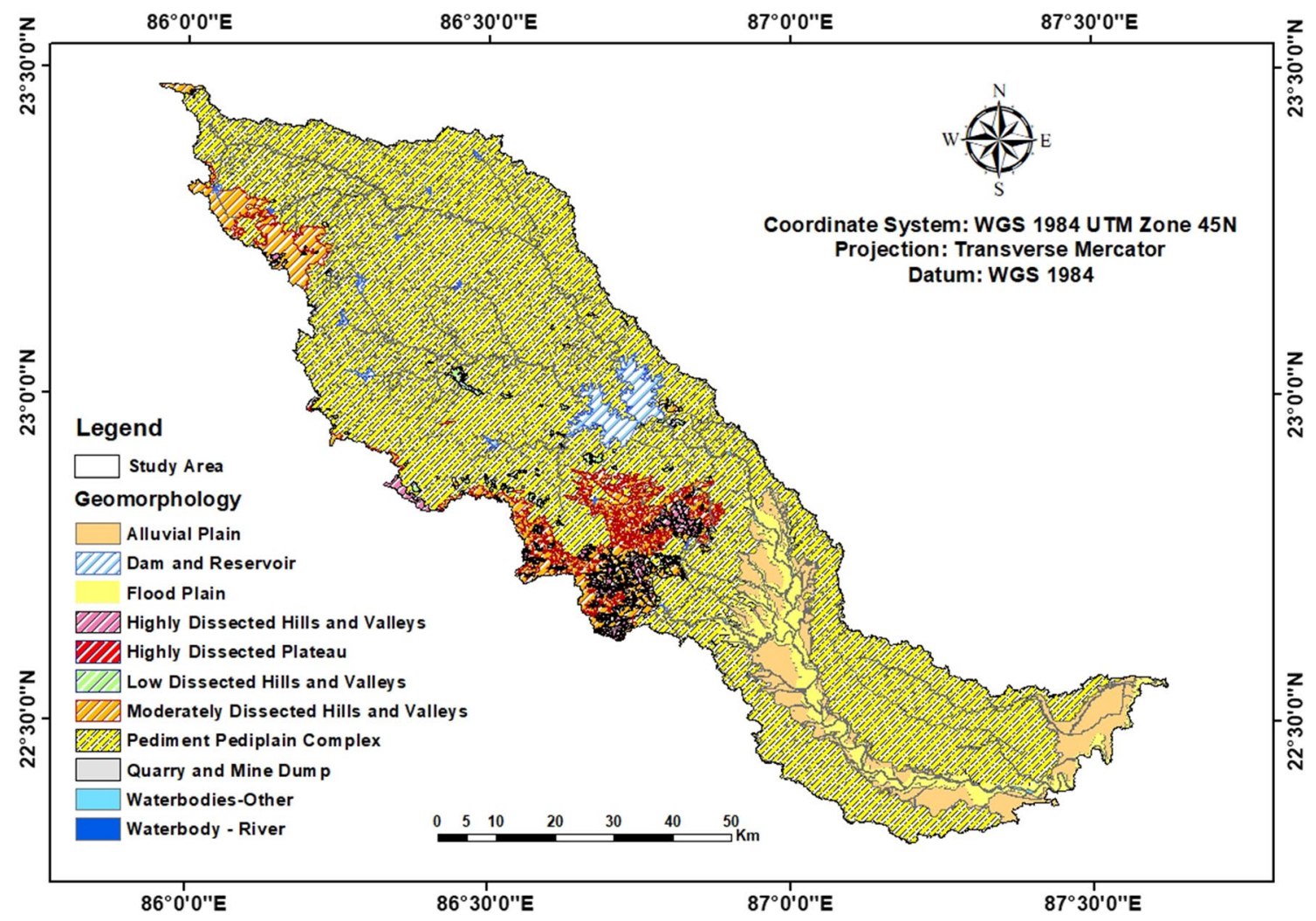

Fig. 5 Spatial map of geomorphology showing different land features of Kangsabati River basin

shallow forest and water bodies cover the rest. Water bodies have a heavier load since they are an excellent source of groundwater replenishment. Agricultural fields with dense vegetation also play a part in recharging the groundwater, and as a result, they have a high weight. The rates of infiltration are proportional to the density of the vegetation, as higher infiltration rates and less runoff are encouraged. As a result, the vegetation-covered surface receives significant weighting. However, because they provide a low infiltration rate, bare ground and built-up areas have been given a low weighting.

\section{Drainage density}

The course of a stream per unit area in a basin region is referred to as drainage density (Horton, 1932; Strahler, 1952). The nature and structure of rocks, soil qualities, and slope gradient, among other factors, all influence drainage density (Manap et al. 2013). The density of drainage is measured by how near the channels are spaced. The opposite functional feature of permeability is the drainage density of a river basin. Increased runoff results from higher drainage density, which reduces water infiltration into the subsurface and vice versa (Bera et al. 2019).
$D d=\sum_{i=1}^{i=n} \frac{D i}{A}\left(k m^{-1}\right)$

where $\sum D i$ is the total stream length in the grid $(\mathrm{km})$ and $A$ is the grid area $\left(\mathrm{km}^{2}\right)$.

The drainage density of the Kangsabati River basin has been classified into five classes, i.e., very low (0.04-0.68 km/km2), low (0.69-1.32 km/km2), moderately low (1.33-1.97 km/km2), high (1.98-2.61 km/km2), and very high $(2.62-3.25 \mathrm{~km} / \mathrm{km} 2)$, covering an area of 914.63 $\mathrm{km} 2,2544.12 \mathrm{~km} 2,2107.35 \mathrm{~km} 2,820.61 \mathrm{~km} 2$, and 101.18 $\mathrm{km} 2$, respectively (Fig. 9). Low and very low drainage density zones make up roughly 53.13 percent of the total area, and they have higher weightage values than high drainage density zones.

\section{Rainfall}

In the research area, rainfall is the principal source of groundwater recharge, and it plays an important role in the hydrological cycle. Rainfall nourishes the region's rivers while also regulating groundwater levels. Rainfall is responsible directly for the recharge potential of groundwater as it helps in groundwater storage through infiltration 


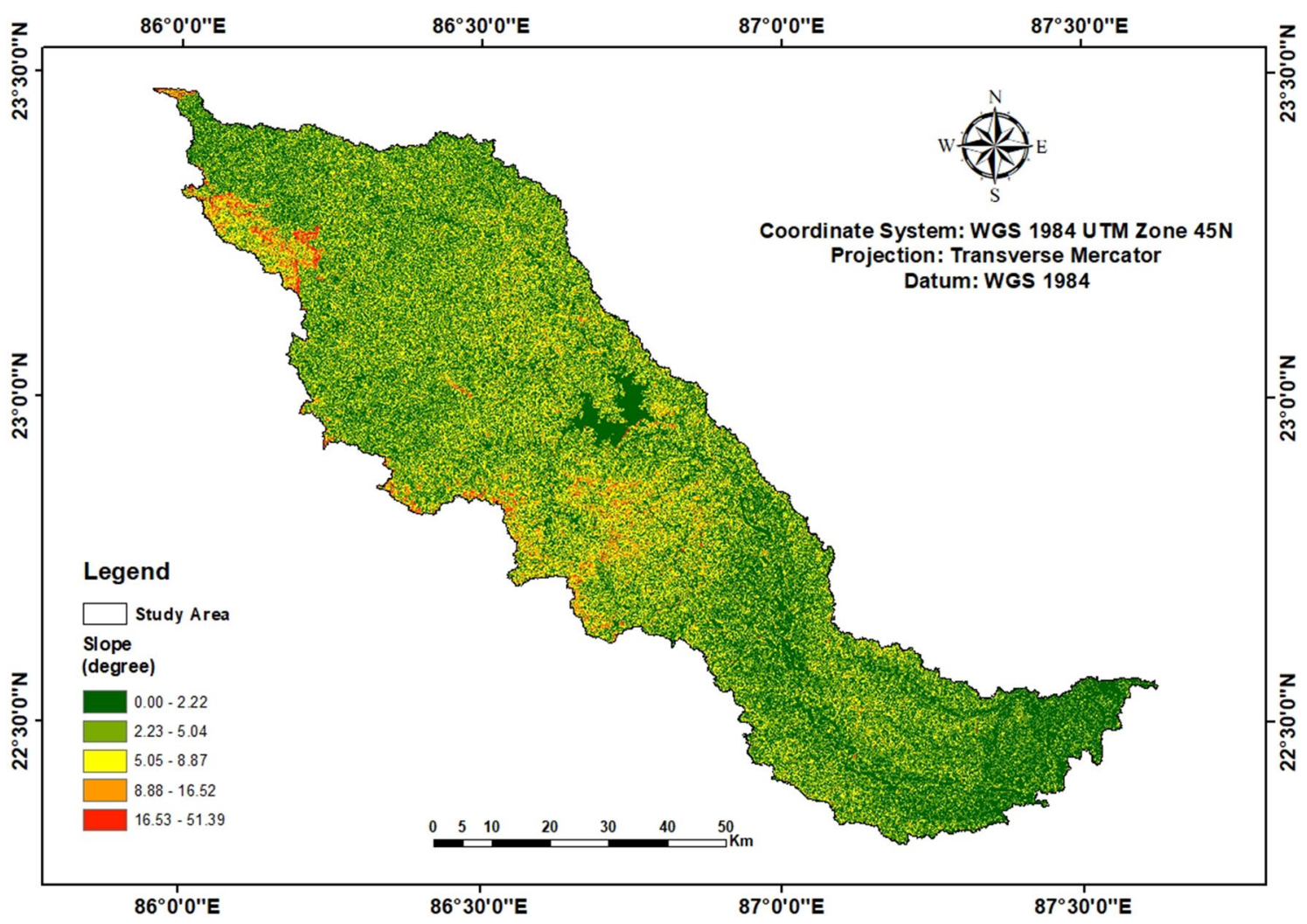

Fig. 6 Spatial distribution of land slope in Kangsabati River basin

process. The pace of infiltration is affected by the amount of rain and how long it lasts. Short-duration, high-intensity rain causes more surface runoff and less infiltration, whereas long-duration, low-intensity rain causes a higher infiltration rate than runoff (Adhikary et al. 2018; Bera et al. 2020; Ibrahim-Bathis and Ahmed 2016). Rainfall data from the years 2010 to 2019 were used in this investigation. The annual rainfall is between 1332.07 and $1599.92 \mathrm{~mm}$. On ArcGIS, the geographical distribution of rainfall was created using the kriging interpolation method. The rainfall map was reclassified into five classes such as very low (1332.07-1378.47 mm), low (1378.48-1421.70 mm), moderate (1421.71-1477.59 mm), high (1477.60-1534.54 mm), and very high (1534.55-1599.92 mm) (Fig. 10).

\section{Soil}

Fluvisols are relatively young soils with little horizon stratification; they often exhibit AC profiles and are brown (aerated soils) or grey (waterlogged soils) in color. They can range in texture from coarse sand in levee soils to thick clays in basin locations. Luvisols have a (greyish) brown to brown or red argic subterranean horizon over a brown to dark brown surface horizon. Leptosols are relatively shallow soils with little expansion that occur on hard rock or calcareous materials. Deeper soils on gravelly and stony parent materials that lack fine earth are also included. There are soils having a lot of shrinking/swelling clay minerals in them. Clay minerals compress and swell, causing selfmixing. Organic matter content is varied, and the color is dark (1-6 percent). Archisols have porous surface soils that are protected by a protective forest canopy. The precious A-horizon degrades and slakes to form a hard surface crust when the forest is destroyed. The crust prevents enough penetration. Cambisols are distinguished by the paucity of illuviated clay, organic content, and aluminum and/or iron compounds, as well as minor or moderate weathering of the parent material (Fig. 11).

\section{Curvature}

Curvature values are used to portray the morphology of regional geometry. A convex surface has a positive curvature, while a concave surface has a negative curvature. The value zero denotes a flat surface. Because soil thickness is relatively higher in areas with concave slopes, soils in these areas continue to gather more water than soils in areas with convex slopes. Convex slopes, on the other hand, shed more surface runoff than concave slopes. The study area was divided into three categories based on slope curvature. These 


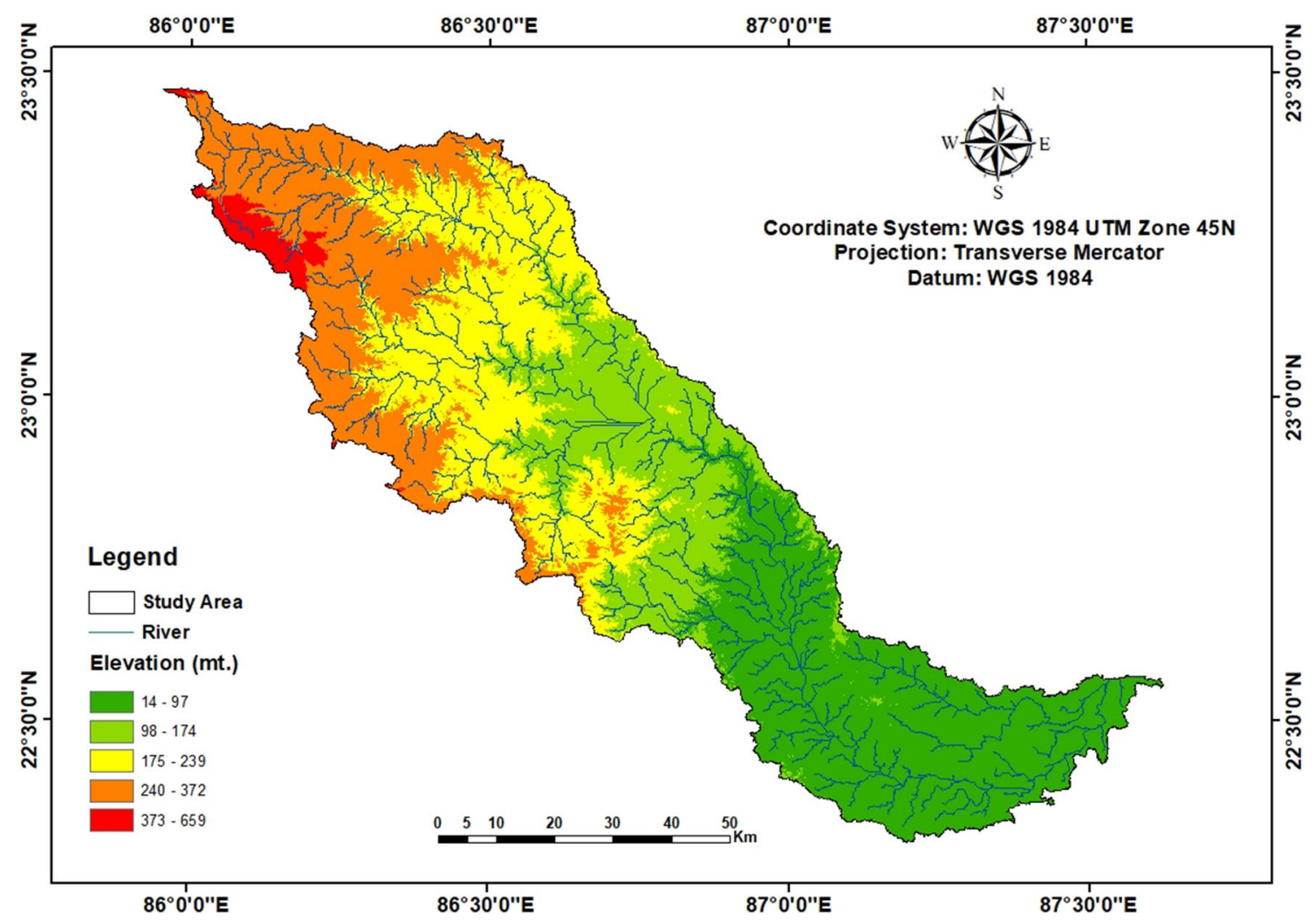

Fig. 7 Spatial distribution of elevation of lands within Kangsabati River basin

are concave (-10.14 to -0.63$)$, flat $(-0.62$ to 0.27$)$, and convex (0.28 to 10.59$)$ (Fig. 12). The study area is mostly flat, with concave and convex profiles covering 11.84 percent and 25.63 percent of the study area, respectively.

\section{Topographic wetness index}

The topographic wetness index (TWI) was first developed by Beven and Kirkby (1979) as part of a runoff model. In a regional topography, TWI represents the overall allocation of wetness scenarios. In simple terms, it represents the slope-to-specific catchment area ratio. This index determines the water accumulation propensity as well as the gravitational attraction's proclivity to relocate water downslope. TWI values of Kangsabati River basin vary from 3.22 to 20.74. Within the Kangsabati River basin, TWI was classified into five classes, i.e., extensively high (11.55-20.74), high (9.00-11.54), moderate (7.42-8.99), low (6.25-7.41), and very low (3.22-6.24) (Fig. 13). The normalized TWI divides recharge zones into two categories: discharge zones and likely recharge zones. TWI values are high in areas with a lot of flow accretion and linear slopes. Rainfall runoff characterizes recharge zones, which allow water to permeate into the soil and so reach the underlying water table, whereas discharge zones are defined by rainwater runoff.
TWI is represented by the following formula:

$T W I=\ln \left(\frac{A s}{\tan \beta}\right)$

where As is the specific catchment area and $\tan \beta$ is the slope angle of the specific grid.

\section{Groundwater Potential Zone}

The Kangsabati River basin's groundwater potential zones (GPZ) were created by overlaying weighted factors such as geomorphology, geology, land use, drainage, elevation, slope, lineament, soil, rainfall, curvature, and topographic wetness index in the spatial analyst tool of ArcGIS using AHP and GIS techniques. Overlay analysis is a multi-criteria assessment that involves awarding a rank to individual factors and then allocating a weightage of sub-factors to that specific feature based on its impact on the criterion (Barik et al. 2016). The Kangsabati River basin's predicted GPZ was divided into five zones: very low (28.93 percent of the area), low (30.56 percent of the area), moderate (19.75 percent of the area), high (14.11 percent of the area), and very high (14.11 percent of the area) (6.11 percent of the area) (Fig. 14, Table 7). Because of the accessibility of loamy 


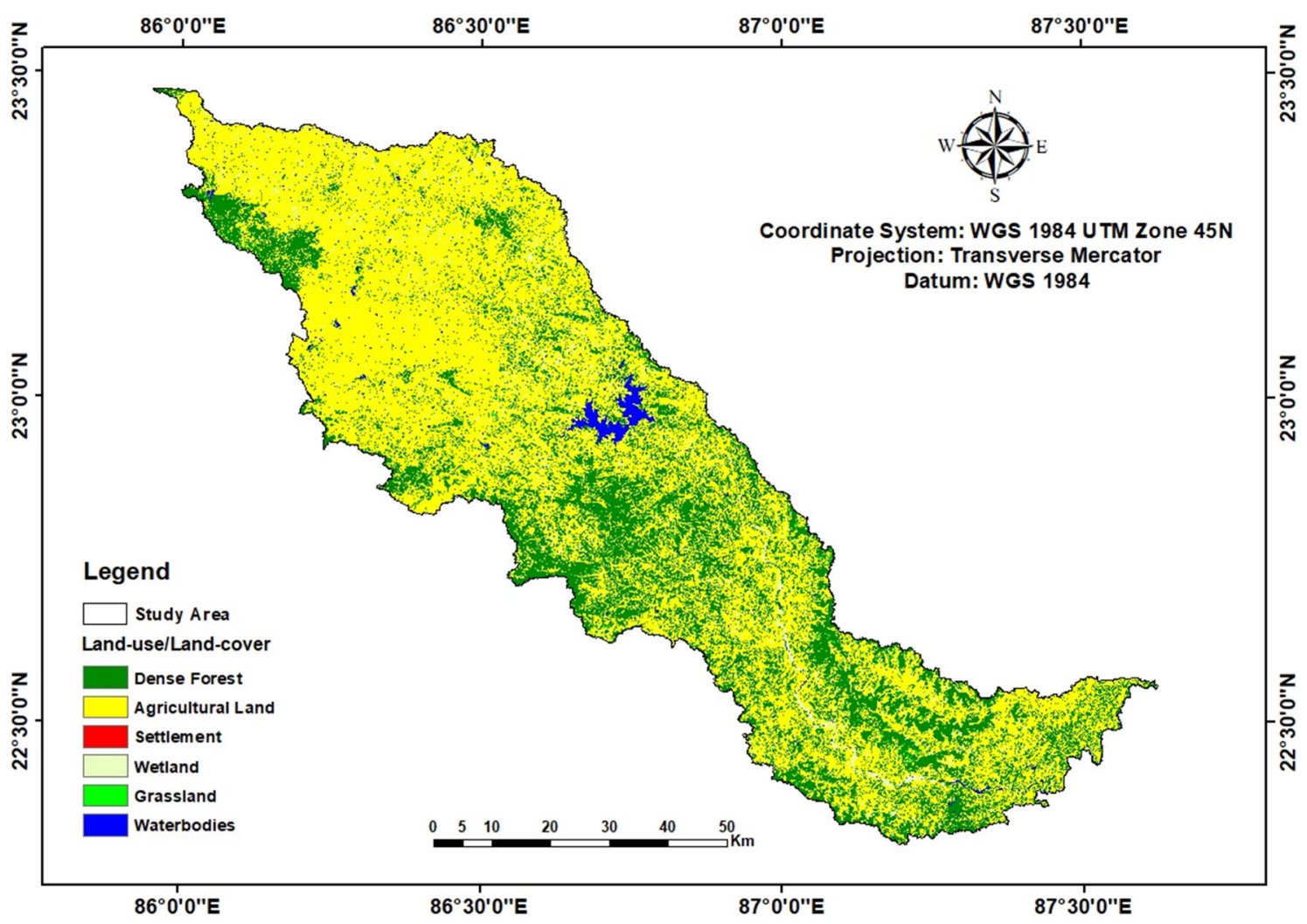

Fig. 8 Spatial map of land use/land cover in Kangsabati River basin

textured well-drained soil, high intensity of rainfall, existence of lineament, gentle slope, and massive agricultural land with excellent infiltration capability, the findings demonstrate that the fantastic GPZ was focused in the central and southeastern parts of the basin, especially in Godapiasal, Raipur, Medinipur, and Khemasuli regions. Rainfall is heaviest in the basin's southeastern section. The northwestern half of the research area (Kotshila, Jhalda, Purulia, Aharrah, Kantadihi, and Barabazar regions) has very poor or low prospective owing to the combination of poorly drained soil and fine-grained basaltic hard rock beneath, which makes groundwater recharge difficult. Geomorphology, slope, land cover, and soil type are the key characteristics that may have an impact on groundwater potential in this area. In the current environment of high demand for groundwater, identifying potential groundwater zones is critical since the perspective of any resource allows for reconsideration and further improvement in that resource. As a result, the delineation of a prospective groundwater zone in the Kangsabati River basin gives regional planners a notion of how to best manage the available water and contribute to long-term development.

\section{Validation of GWPZ using water table data}

The receiver operating characteristic (ROC) curve has been used to depict the amount of precision of groundwater potential zones (Mohammady et al. 2012; Pradhan, 2013). The data from existing boreholes are referenced to the groundwater potential zone map in this graph. The area under the curve (AUC) of the ROC curve (Fig. 15) is 0.745, which corresponds to 74.5 percent. As a result of this model's accuracy of greater than 70\%, the AHP approach can be acknowledged as a straightforward tool for generating groundwater potential zones.

Groundwater fluctuation map is created by researching the region's seasonal groundwater fluctuation (CGWB 2019). Low groundwater potentiality is found in areas where water levels fluctuate a lot, and high groundwater potentiality is found in areas where water levels fluctuate less. In this study, 35 wells were examined for the purpose of determining the depth of water level data for the years 2019 and 2020. With the use of IDW interpolation, pre-monsoon and postmonsoon maps were constructed based on the obtained data. The maps show how the water level in the Kangsabati River basin varies over time. The northwestern part of the basin has a deeper depth than the other regions, according to the 


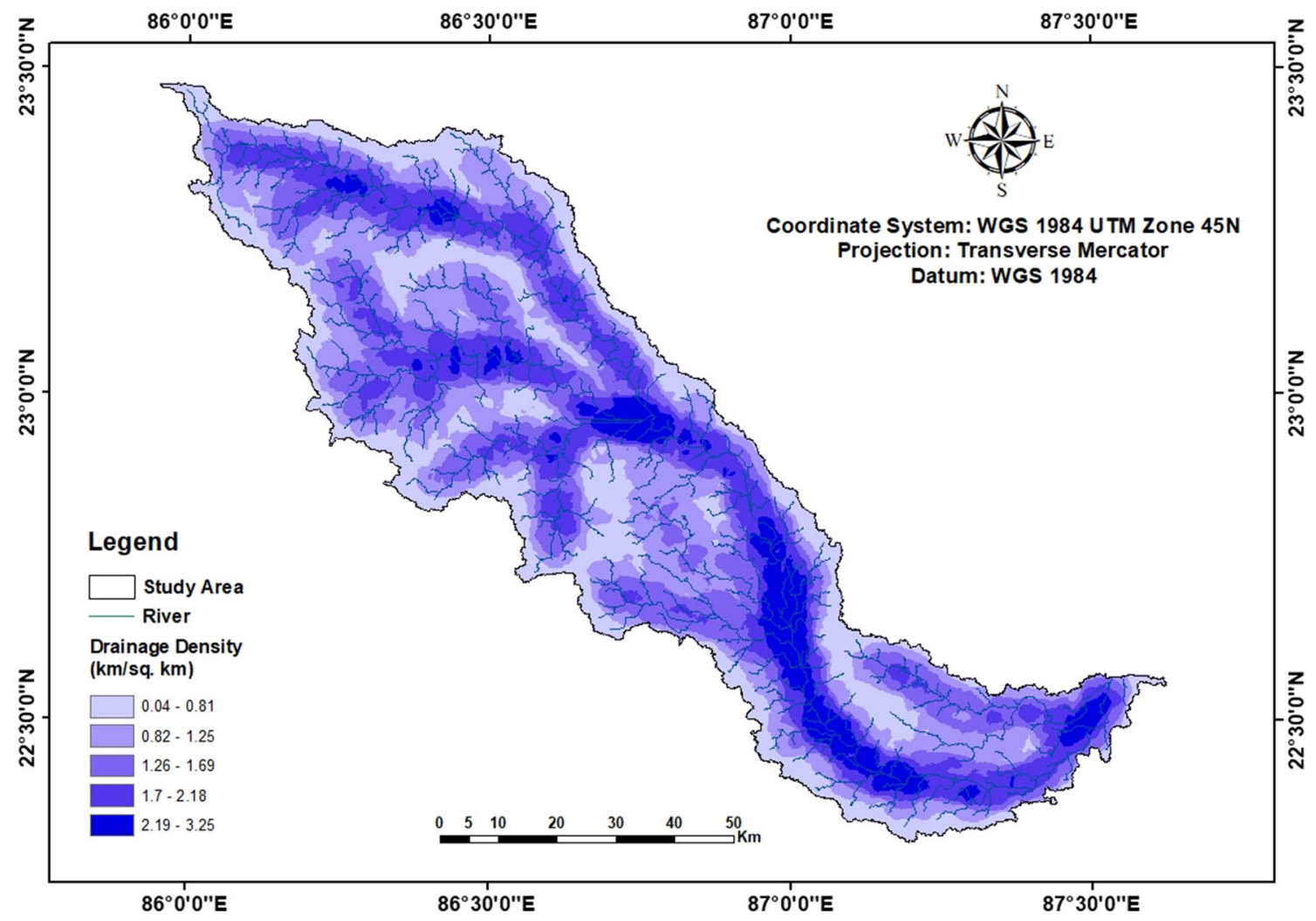

Fig. 9 Spatial map of drainage density of Kangsabati River basin

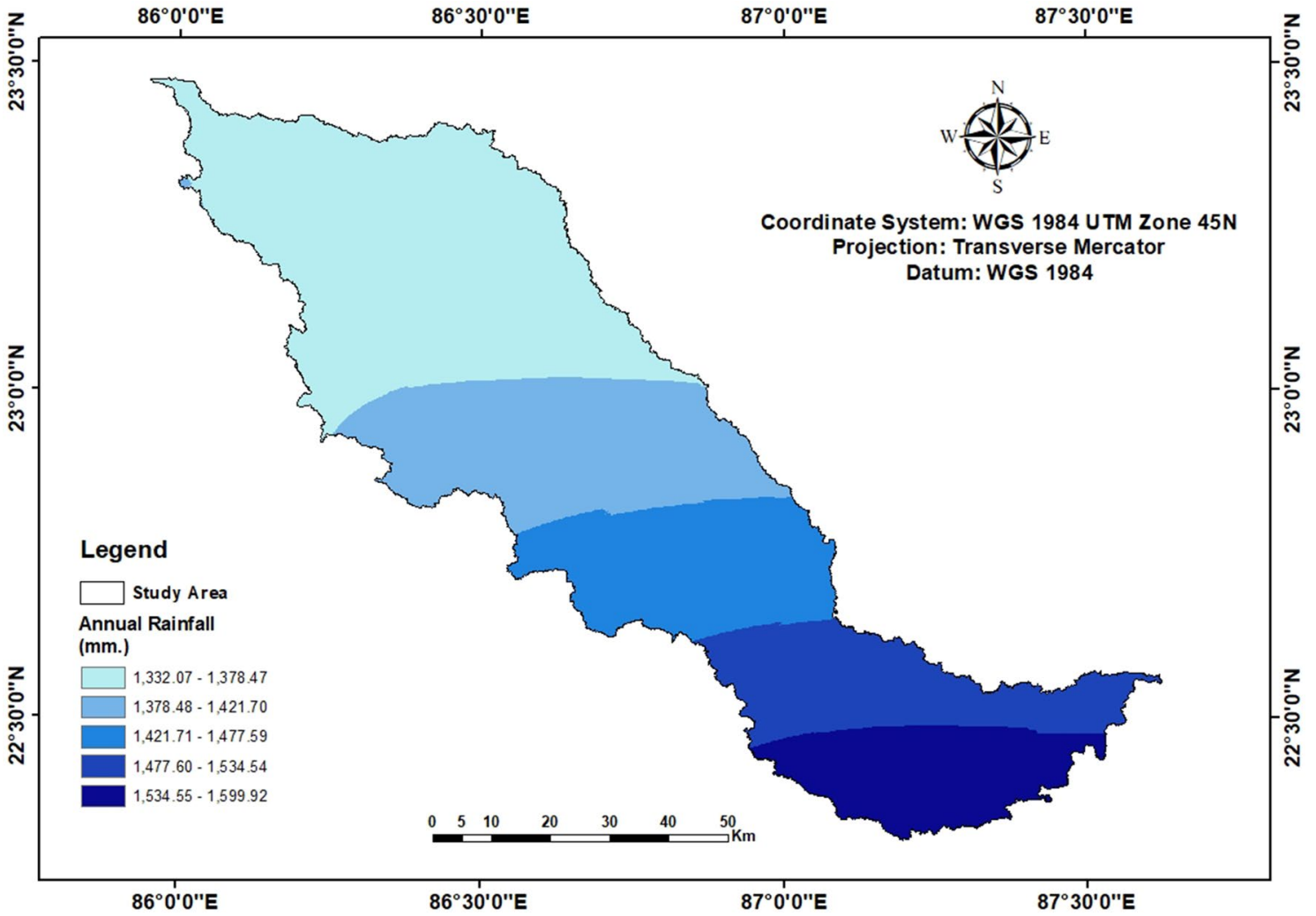

Fig. 10 Rainfall distribution map of Kangsabati River basin 


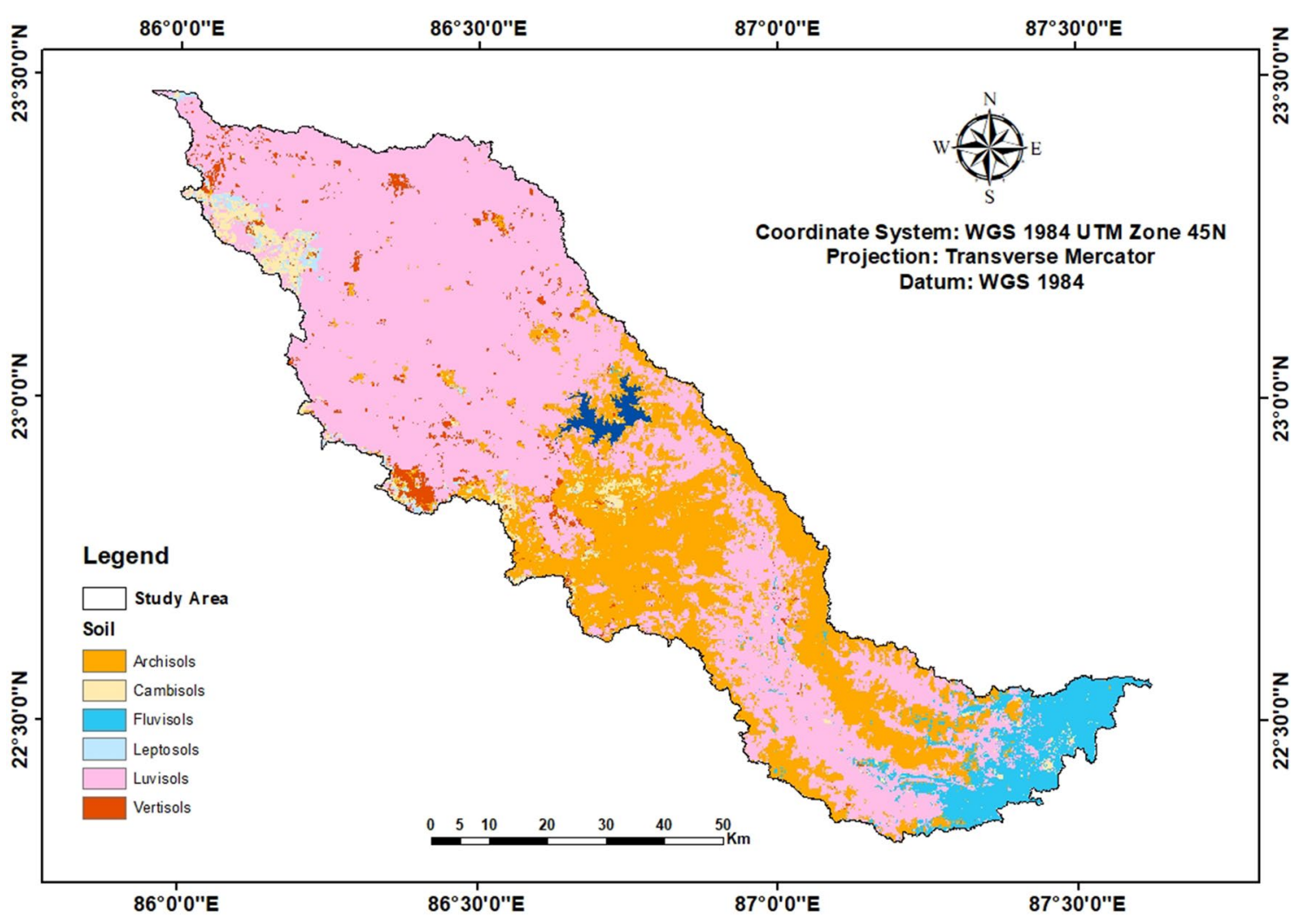

Fig. 11 Soil map showing spatial distribution of different soil orders in Kangsabati River basin

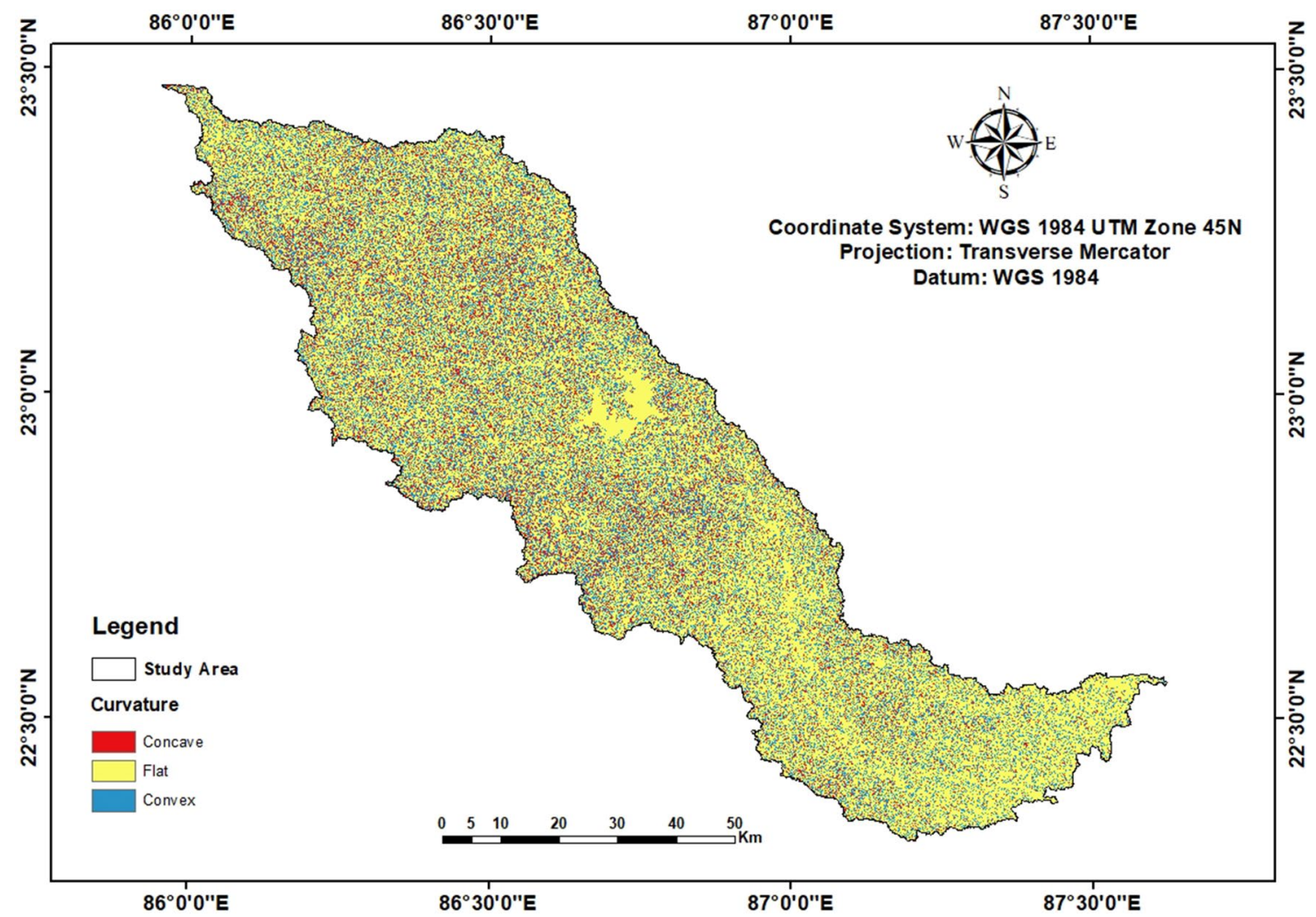

Fig. 12 Curvature map showing spatial distribution of different slope types in Kangsabati River basin 


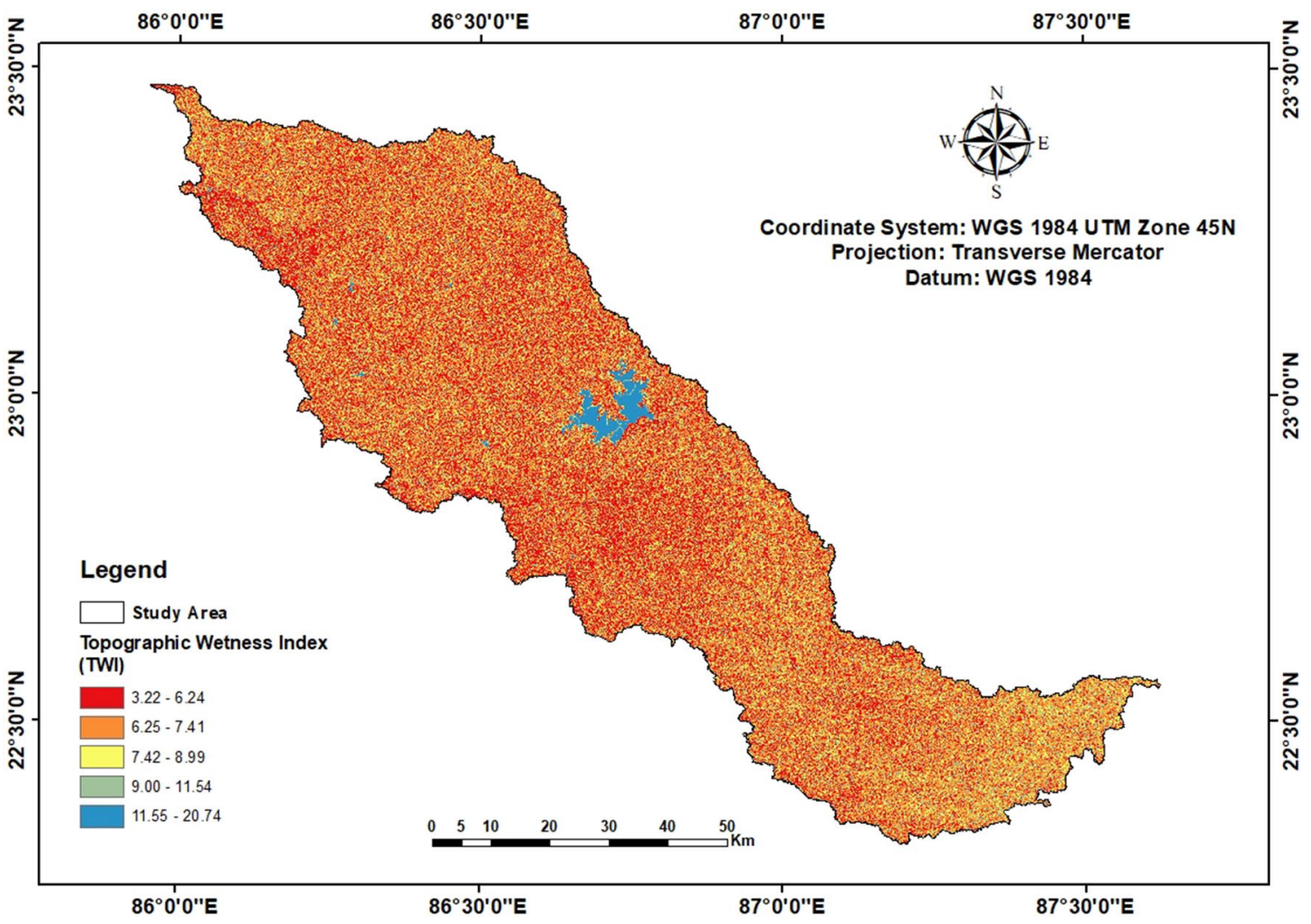

Fig. 13 Spatial distribution of topographic wetness index within Kangsabati River basin

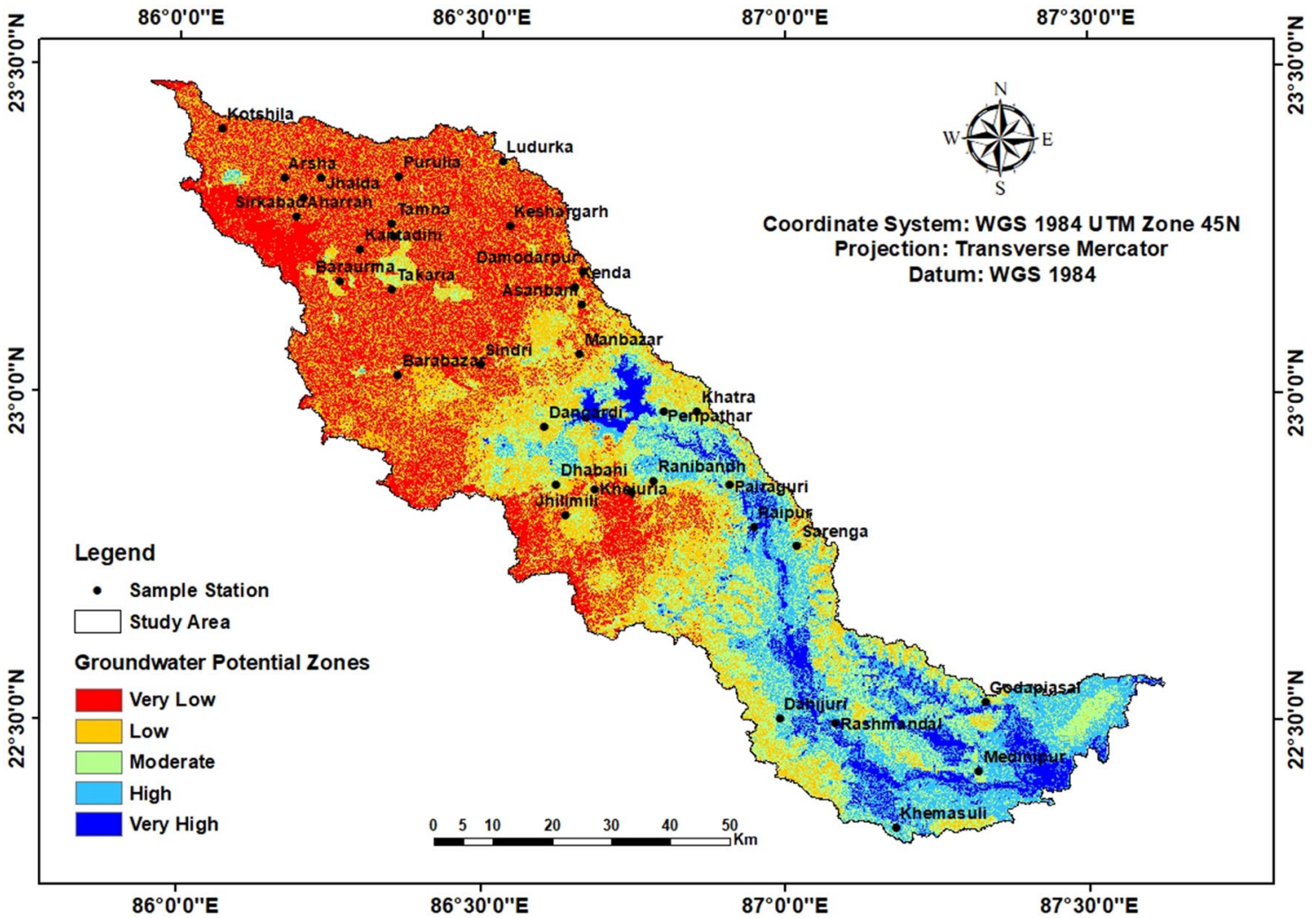

Fig. 14 Map showing the spatial distribution of groundwater potential zones in Kangsabati River basin 
Table 7 Areal coverage of different groundwater potential zones within Kangsabati River basin

\begin{tabular}{lcc}
\hline Degree of potentiality & Area $\left(\mathrm{km}^{2}\right)$ & $\%$ of area \\
\hline Very low potentiality & 1862.546 & 28.93661 \\
Low potentiality & 1967.532 & 30.56769 \\
Moderate potentiality & 1271.625 & 19.75604 \\
High potentiality & 941.1759 & 14.62216 \\
Very high potentiality & 393.7617 & 6.117503 \\
\hline
\end{tabular}

pre-monsoon map. In the post-monsoon season, the center and southeast regions of the basin have shallower depths than the north and northwestern parts. From the raster calculator method, groundwater fluctuation map (Fig. 16) has been created. This map indicated that in the high GWPZ, the groundwater fluctuation is low and vice versa. Based on this finding, a scatter plot has been made to understand the relation between GWPZ and groundwater table fluctuation (Fig. 17). Groundwater potential zone has a negative relationship with groundwater fluctuation, according to the scatter graphs. As a result, the groundwater potential map and the groundwater volatility map are extremely accurate.

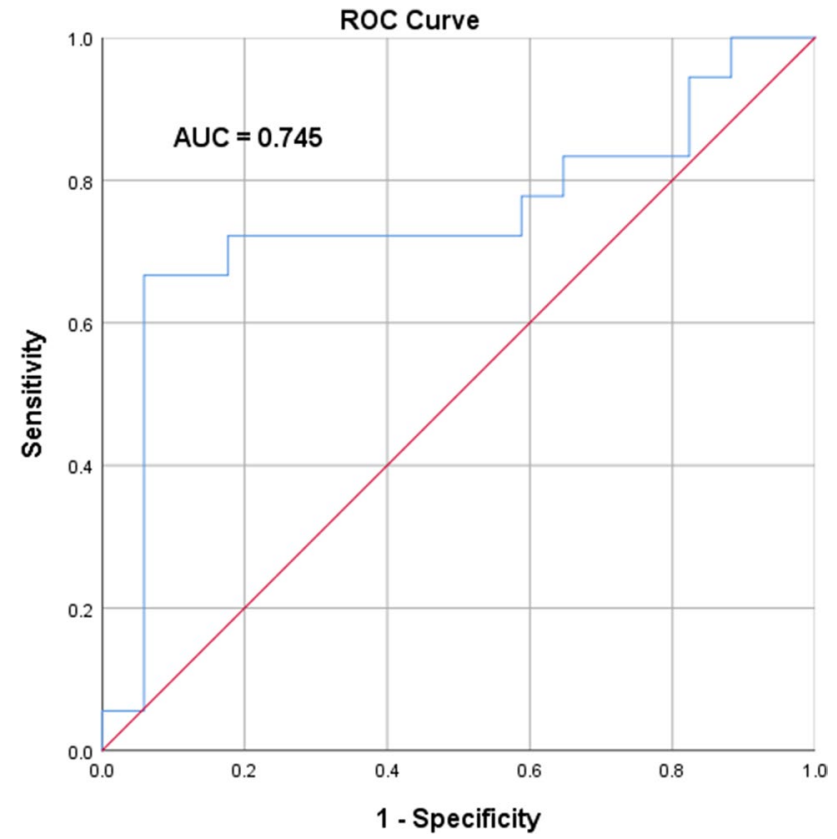

Fig. 15 Receivers operating characteristic (ROC) curve of Kangsabati River basin showing the accuracy of the present study

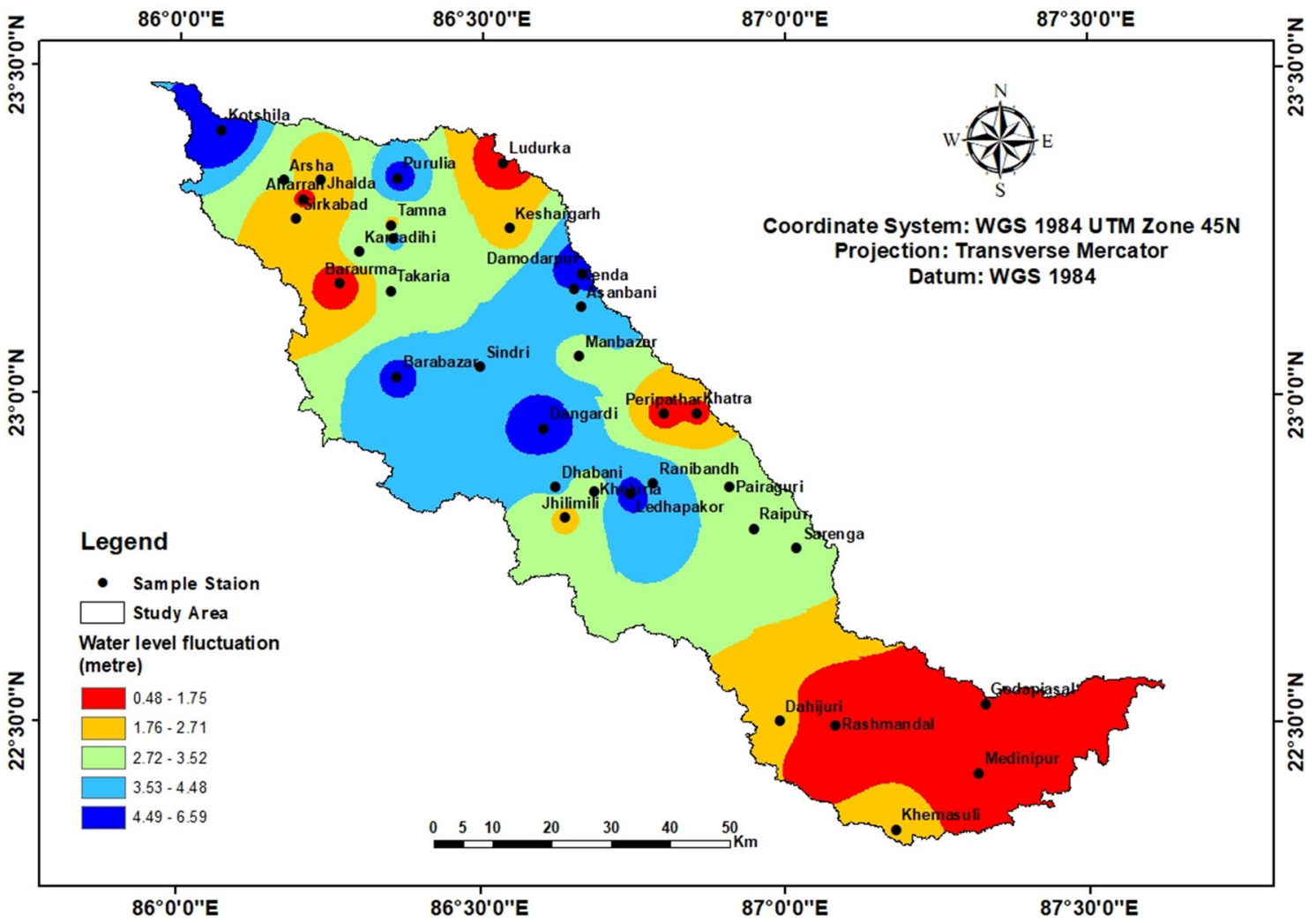

Fig. 16 Map showing the spatial variation of groundwater fluctuation in Kangsabati River basin 


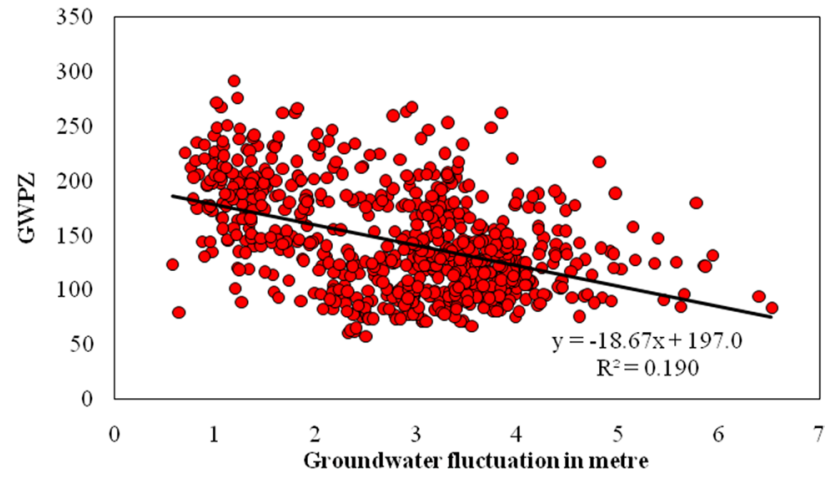

Fig. 17 Relationship between the water level fluctuation and the groundwater potential zone

\section{Conclusion}

The AHP approach, in combination with remote sensing and GIS, was successfully used to designate groundwater potential zones in the Kangsabati River basin in this study. According to the findings, approximately 14.62 percent and 6.11 percent of the region are in high to extremely high potential zones. As a result, the study of groundwater potential zones encompasses the interaction between groundwater occurrence and various physical characteristics such as geology, geomorphology, rainfall, drainage, lineament, curvature, TWI, and so on. The applicability of the AHP method for identifying groundwater potential zones using ROC curve is also discussed in the study. As a result, it is a systematic investigation in which a quantitative method was used to manage the groundwater supply. In an era of resource depletion, this study is extremely useful since the final map will be useful to authorities involved in land use planning and water resource management. The results were confirmed using pre-monsoon and post-monsoon groundwater depths to ensure that the applied approach was appropriate for the study, indicating that it was.

Acknowledgements The authors show their kind acknowledgment to the Dept. of Geography and Microbiology, Raja N. L. Khan Women's College (Autonomous), Medinipur, West Bengal, India, for their laboratory facilities and kind encouragement.

Author's Contributions PK Shit conceptualized and planned the study and reviewed and edited the manuscript. AG conducted the survey, analyzed the data, and interpreted the results. GSB reviewed and edited the manuscript. PPA reviewed and edited the manuscript. BB supervised the study and reviewed and edited the manuscript. All authors have read and approved the final manuscript.

Funding This research was supported by the Department of Geography, Raja N. L. Khan Women's College (Autonomous), affiliated to Vidyasagar University, Midnapore, West Bengal, India. The author (P. K. Shit) gratefully acknowledges West Bengal DSTBT for financial support through R\&D Research Project Memo no. 104(Sanc.)/ ST/P/S\&T/ 10G-5/2018

\section{Declarations}

Conflict of interest The authors declare that they have no conflict of interest.

Data availability The datasets used and analyzed during the current study are available from the corresponding author on reasonable request.

Open Access This article is licensed under a Creative Commons Attribution 4.0 International License, which permits use, sharing, adaptation, distribution and reproduction in any medium or format, as long as you give appropriate credit to the original author(s) and the source, provide a link to the Creative Commons licence, and indicate if changes were made. The images or other third party material in this article are included in the article's Creative Commons licence, unless indicated otherwise in a credit line to the material. If material is not included in the article's Creative Commons licence and your intended use is not permitted by statutory regulation or exceeds the permitted use, you will need to obtain permission directly from the copyright holder. To view a copy of this licence, visit http://creativecommons.org/licenses/by/4.0/.

\section{References}

Adhikary PP, Chandrasekharan H, Dubey SK, Trivedi SM, Dash CJ (2015) Electrical resistivity tomography for assessment of groundwater salinity in west Delhi India. Arab J Geosci 8(5):2687-2698

Adhikary PP, Hombegowda HC, Barman D, Madhu M (2018) Soil and onsite nutrient conservation potential of aromatic grasses at field scale under a shifting cultivated, degraded catchment in Eastern Ghats India. Int J Sed Res 33(3):340-350

Baalousha HM, Barth N, Ramasomanana FH, Ahzi S (2018) Groundwater recharge estimation and its spatial distribution in arid regions using GIS a case study from Qatar karst aquifer. Model Earth Syst Environ 4(4):1319-1329

Barik KK, Jeet R, Annaduari R, Tripathy JK (2016) Hydrogeological mapping and identification of groundwater recharge potential zone of Reamal block Deogarh District Odisha-a geospatial technology approach. Int J Adv Remote Sens GIS 5:1829-1843

Bera A, Mukhopadhyay BP, Das D (2019) Landslide hazard zonation mapping using multi-criteria analysis with the help of GIS techniques: a case study from eastern Himalayas, Namchi, South Sikkim. Nat Hazards 96:935-959

Bera A, Mukhopadhyay BP, Barua S (2020) Delineation of groundwater potential zones in Karha river basin, Maharashtra, India, using AHP and geospatial techniques. Arab J Geosci 13:693. https://doi. org/10.1007/s12517-020-05702-2

Beven KJ, Kirkby MJ (1979) A physically based, variable contributing area model of basin hydrology. HydrolSci Bull 24:43-69

Bhattacharya RK (2018) Geo-environmental consequences of instream sand mining: case specific studies on Kangsabati river from Khatra to Chouka, West Bengal. Unpublished Thesis submitted on. Vidyasagar University, Medinipur, WB

Central Ground Water Board (2014) Dynamic ground water resources of India. Ministry of Water Resources, River Development and Ganga Rejuvenation, Government of India

CGWB (2014) Groundwater scenario of Himalayan region. Government of India, India

CGWB (2019) Groundwater year book of West Bengal and Andaman and Nicobar Island 2019-20. Ministry of Water Resources, Government of India. http://www.cgwb.gov.in 
Chen Y, Khan S, Paydar Z (2010) To retire or expand? A fuzzy GIS based spatial multi-criteria evaluation framework for irrigated agriculture. Irrig Drain 59(2):174-188

Choudhary BS, Kumar M, Roy AK, Ruhal DSPR (1996) Application of remote sensing and Geographic Information Systems in ground water investigations in Sohna block, Gurgaon district, Haryana (India). Int Arc-Hive Photog Rem Sens XXXI B6:21

Chowdhury A, Jha MK, Chowdhury VM, Mal BC (2009) Integrated remote sensing and GIS based approach for accessing groundwater potential in west Medinipur district, West Bengal India. Int J Rem Sens 30(1):231-250

Dar IA, Sankar K, Dar MA (2010) Remote sensing technology and geographic information system modeling: an integrated approach towards the mapping of groundwater potential zones in Hardrock terrain. Mamund Basin J Hydrol 394(3-4):285-295

Das N, Mukhopadhyay S (2018) Application of multi-criteria decision making technique for the assessment of groundwater potential zones: a study on Birbhum district, West Bengal, India. Environment, Development and Sustainability, 1-25

Das B, Pal SC, Malik S, Chakrabortty R (2018) Modeling groundwater potential zones of Puruliya district, West Bengal, India using remote sensing and GIS techniques. Geology, Ecology, and Landscapes, $1-15$

Dutta S, Roy S (2012) Determination of erosion surfaces and stages of evolution of Sangra drainage basin in Giridih district, Jharkhand. India Int J GeomatGeosci 3(1):63-73

Feizizadeh B, Blaschke T (2013) GIS-multicriteria decision analysis for landslide susceptibility mapping: comparing three methods for the Urmia lake basin. Iran Nat Hazards 65(3):2105-2128

Ghosh PK, Bandyopadhyay S, Jana NC (2016) Mapping of groundwater potential zones in hard rock terrain using geoinformatics: a case of Kumari watershed in western part of West Bengal. Model Earth Syst Environ. 2(1):1

Hajkowicz S, Higgins A (2008) A comparison of multiple criteria analysis techniques for water resource management. Eur J Oper Res 184:255-265

Holden J (ed) (2014) Water resources: an integrated approach. Routledge

Jankowski P, Richard L (1994) Integration of GIS-based suitability analysis and multicriteria evaluation in a spatial decision support system for route selection. Environ Plann B 21(3):323-340

Jenks GF (1967) The data model concept in statistical mapping. Int Yearb Cartogr 7:186-190

Jha MK, Chowdary VM, Chowdhury A (2010) Groundwater assessment in Salboni Block, West Bengal (India) using remote sensing, geographical information system and multi-criteria decision analysis techniques. Hydrogeol J 18(7):1713-1728. https://doi. org/10.1007/s10040-010-0631-z

Jhariya DC, Kumar T, Gobinath M, Diwan P, Kishore N (2016) Assessment of groundwater potential zone using remote sensing, GIS and multi-criteria decision analysis techniques. J Geol Soc India $88: 481-492$

Kaliraj S, Chandrasekar N, Magesh NS (2014) Identification of potential groundwater recharge zones in Vaigai upper basin, Tamil Nadu, using GIS-based analytical hierarchical process (AHP) technique. Arab J Geosci 7(4):1385-1401

Madrucci V, Taioli F, Cesar de Araujo C (2008) Groundwater favorability map using GIS multicriteria data analysis on Crystalline terrain, Sao Paulo State, Brazil. J Hydrol 357:153-173

Magesh NS, Chandrasekar N, Soundranayagam JP (2012) Delineation of groundwater potential zones in Theni district, Tamil Nadu, using remote sensing GIS and MIF Techniques. Geosci Front 3(2): 189-196

Mahala A (2020) The significance of morphometric analysis to understand the hydrological and morphological characteristics in two different morpho-climatic settings. Appl Water Sci 10:33. https:// doi.org/10.1007/s13201-019-1118-2

Manap MA, Sulaiman WNA, Ramli MF, Pradhan B, Surip N (2013) A knowledge-driven GIS modeling technique for groundwater potential mapping at the Upper Langat Basin, Malaysia. Arab J Geosci 6:1621-1637

Marinoni O (2004) Implementation of the analytical hierarchy process with VBA in ArcGIS. ComputGeosci 30(6):637-646

Mohammady M, Pourghasemi HR, Pradhan B (2012) Landslide susceptibility mapping at Golestan Province, Iran: A comparison between frequency ratio, Dempster Shafer, and weights-of evidence models. J Asian Earth Sci 61:221-236

Murmu P, Kumar M, Lal D, Sonker I, Singh SK (2019) Delineation of groundwater potential zones using geospatial techniques and analytical hierarchy process in Dumka district, Jharkhand, India. Groundw. Sustain. Dev. 9, 100239

Murthy KSR, Mamo AG (2009) Multi-criteria decision making evaluation in groundwater zones identification in Moyale-Teltelesub basin, South Ethiopia. Int J Remote Sens 30:2729-2740

Nag SK, Lahiri A (2012) Hydrochemical characteristics of groundwater for domestic and irrigation purposes in Dwarakeswar watershed area, India. Am J Clim Change 1:217-230

Nag SK, Ghosh P (2012) Delineation of groundwater potential zone in Chhatna Block, Bankura district, West Bengal, India using remote sensing and GIS tech Env Earth Sci

Neelakantan R, Yuvaraj S (2012) Evaluation of groundwater using geospatial data- a case study from Salem taluk Tamil Nadu, India. Int J Rem Sens Geosci 1(2):7

Pan S (2013) Application of remote sensing and GIS in studying changing river course in Bankura District, West Bengal. Int J Geomatics Geosci 4(1):149-163

Pande CB, Khadri SFR, Moharir KN et al (2017) Assessment of groundwater potential zonation of Mahesh River basin Akola and Buldhana districts, Maharashtra, India using remote sensing and GIS techniques. Sust Water Res Manag 4:1-15

Patra S, Mishra P, Mahapatra SC (2018) Delineation of groundwater potential zone for sustainable development: a case study from Ganga Alluvial Plain covering Hooghly district of India using remote sensing, geographic information system and analytic hierarchy process. J Clean Prod 172:2485-2502. https://doi.org/10. 1016/j.jclepro.2017.11.161

Pradhan B (2013) A comparative study on the predictive ability of the decision tree, support vector machine and neuro-fuzzy models in landslide susceptibility mapping using GIS. Comput Geosci $51: 350-365$

Prasad RK, Mondal NC, Banerjee P, Nandakumar MV, Singh VS (2008) Deciphering potential groundwater zone in hard rock through the application of GIS. Environ Geol 55(3):467-475

Rahmati O, NazariSamani A, Mahdavi M, Pourghasemi HR, Zeinivand H (2015) Groundwater potential mapping at Kurdistan region of Iran using analytic hierarchy process and GIS. Arab J Geosci 8(9):7059-7071

Ramu MB, Vinay M (2014) Identification of ground water potential zones using GIS and remote sensing techniques: a case study of Mysore taluk-Karnataka. Int J Geomat Geosci 5(3):393-403

Razandi Y, Pourghasemi HR, Neisani NS (2015) Application of analytical hierarchy process, frequency ratio and certainty factor models for groundwater potential mapping using GIS. Earth Sci Inf 8(4):883-886

Saaty TL (1980) The analytic hierarchy process: Planning, priority setting, resource allocation. McGraw Hill, NewYork

Saaty TL (1990) How to make a decision the analytic hierarchy process. Eur J Oper Res 48:9-26

Saaty TL (1999) Fundamental of analytic network process. In: International symposium of the analytic hierarchy process (ISAHP), Kobe, Japan 
Saaty TL, Vargas LG (1991) Prediction, projection and forecasting. Kluwer Academic Publishers, Dordrecht, $251 \mathrm{pp}$

Saha S (2017) Groundwater potential mapping using analytical hierarchical process a study on Md Bazar Block of Birbhum District West Bengal. Spat Inf Res 25(4):615-626

Sajikumar N, Pulikkottil G (2013) Integrated remote sensing and GIS approach for groundwater exploration using analytic hierarchy process technique. Int J Innov Res Sci Eng Technol 2:66-74

Singh PK, Kumar S, Singh UC (2011) Evaluation de la ressource en eaux souterraines dans la zone de Gwalior, Inde, au moyen de données satellitaires: une approche géomorphologique et géophysique intégrée. Hydrogeol J. https://doi.org/10.1007/s10040-011-0758-6

Strahler AN (1952) Dynamics basin geomorphology. Geol Soc Am Bull 63:1117-1142
Te Chow V (2008) Applied hydrology. Tata McGraw-Hill Education Tiwari AK, Lavy M, Amanzio G, De Maio M, Singh PK, Mahato MK (2017) Identification of artificial groundwater recharging zone using a GIS-based fuzzy logic pproach: a case study in a coal mine area of the Damodar Valley India. Appl Water Sci 7(8):4513-4524

Publisher's Note Springer Nature remains neutral with regard to jurisdictional claims in published maps and institutional affiliations. 